\title{
The Neolithic greenstone industry of Chiomonte (northwestern Italy): mineralogy, petrography and archaeometric implications
}

\author{
Roberto Giustetto $^{1,2,3}$, Stefania Padovan ${ }^{4}$, Luca Barale ${ }^{5}$, and Roberto Compagnoni ${ }^{1}$ \\ ${ }^{1}$ Department of Earth Sciences, University of Turin, Via Valperga Caluso 35, Turin, 10125, Italy \\ ${ }^{2}$ NIS - Nanostructured Interfaces and Surfaces Centre, Via Quarello 15/A, Turin, 10135, Italy \\ ${ }^{3}$ INFN - National Institute of Nuclear Physics, Via Giuria 5, Turin, 10125, Italy \\ ${ }^{4}$ Parco Archeologico del Lago Pistono, Piazza IV Novembre 3, Montalto Dora, 10016, Italy \\ ${ }^{5}$ Consiglio Nazionale delle Ricerche, Istituto di Geoscienze e Georisorse, \\ Via Valperga Caluso 35, Turin, 10125, Italy
}

Correspondence: Roberto Giustetto (roberto.giustetto@unito.it)

Received: 18 April 2019 - Accepted: 10 December 2019 - Published: 30 January 2020

\begin{abstract}
The polished stone industry of Chiomonte (Piedmont region, northwestern Italy), dating back to the middle to late Neolithic, has been studied with a multi-analytical approach, including mineralogical, petrographic and morpho-typological issues, with the aim of providing information about the sources of the raw materials and determining the function of this particular settlement in the prehistoric Western Alps. Most of the lithic tools are made of sensu stricto greenstones (i.e. "Na pyroxene rocks" and "Na pyroxene and garnet rocks"), though a large number of serpentinite tools ( $25 \%$ ) also exist. The combined application of X-ray powder diffraction (XRPD), polarising microscopy and Scanning Electron Microscopy coupled with Energy Dispersive Spectrometry (SEMEDS) led to the detection of specific mineral and chemical "markers", pointing to the Chiomonte tools likely having come from the Monviso area. However, other closer supply sources, e.g. small meta-ophiolite units in the Orsiera-Rocciavré mountain range or in the lower Susa valley, cannot be ruled out. The presence, on the many retrieved roughouts and broken tools, of raw, yet unpolished surfaces that are ascribable to pebbles and cobbles from alluvial or glacial deposits, suggests that these rocks had been picked up from local "secondary" sources. The abundance of roughouts and broken tools identifies Chiomonte as a second-order manufacturing site, although it is still unclear whether such an activity was restricted to serving local needs or if it contributed to the circulation of greenstone implements on a wider scale.
\end{abstract}

\section{Introduction}

In the Neolithic, humanity abandoned nomadism and settled permanently in flat lands, dedicating themselves to agriculture and stock raising and transitioning from the use of splintered stone to polished stone. Most of the lithic implements (axes, chisels and hatchets) have been found in archaeological sites spread all over Europe, especially in the Po plain and Western Alps. These tools underwent a vast circulation, as similar relics have been found in southern France, southern Italy, Great Britain (Pétrequin et al., 2002), Slovakia, the Czech Republic, Hungary,
(Spišiak and Hovorka, 2005; Pétrequin et al., 2011; Bendő et al., 2014, 2019), Austria, Bulgaria, Denmark, Germany, Spain (Tsonchev, 1946; Přichystal and Trnka, 2001; Errera et al., 2006; Pétrequin et al., 2008) and Malta (Mancusi, 2017). They are mostly made of sensu stricto greenstones, i.e. high-pressure (HP) metaophiolites marked by toughness and high density (Ricq-de-Bouard, 1993; Giustetto et al., 2008; D'Amico and Starnini, 2009, 2011), mostly consisting of $\mathrm{Na} / \mathrm{Ca}$-pyroxenes, i.e. solid solutions of jadeite (Jd), omphacite and aegirine (Ae). Giustetto and Compagnoni (2014) divided these rocks in two groups: (1) "Na pyroxene rocks", commonly referred to as "jades", includ- 
ing jadeitite (with 95 vol \%-100 vol \% jadeite), omphacitite (with 95 vol \%-100 vol \% omphacite), and mixed Na pyroxenite (with intermediate amounts of jadeite and omphacite), and (2) "Na pyroxene and garnet rocks", made of omphacite plus garnet, including eclogite (with omphacite and garnet in $25 \%$ to $75 \%$ mutual amounts), garnet omphacitite (with 5 vol \%-25 vol \% garnet), and omphacite-garnetite (with 5 vol \%-25 vol \% omphacite). Actually, the term jade includes "jadeite jade" (made of jadeite, $\mathrm{NaAlSi}_{2} \mathrm{O}_{6}$ ) and "nephrite jade" (made of an amphibole of the tremoliteferro-actinolite series: $\left.\mathrm{Ca}_{2}(\mathrm{Mg}, \mathrm{Fe})_{5} \mathrm{Si}_{8} \mathrm{O}_{22}(\mathrm{OH})_{2}\right)$. Only the former will be treated here, though "omphacite jade" (made of omphacite, $\left.(\mathrm{Ca}, \mathrm{Na})\left(\mathrm{Mg}, \mathrm{Fe}^{2+}, \mathrm{Al}\right) \mathrm{Si}_{2} \mathrm{O}_{6}\right)$ will be considered too (D'Amico et al., 2004; Ou Yang, 2006; Ou Yang et al., 2011; McClure, 2012).

These greenstones occur in the alpine geological context as rare and small "primary" outcrops (of a few cubic metres) at high altitude, mainly in the Monviso and Voltri massifs (D'Amico, 2005; Pétrequin et al., 2005a, b, 2006; Compagnoni et al., 2007, 2012) or as boulders, pebbles, or cobbles in "secondary" alluvial deposits, derived from dismantlement in the neighbouring downhill regions (Compagnoni et al., 2006; D'Amico and Starnini, 2006; D'Amico and De Angelis, 2009). The pioneering studies of Gastaldi (1871), Damour (1846) and Franchi (1900) have shown that these greenstones belong to the Internal Piemonte Zone, which includes meta-ophiolite units derived from the LiguriaPiemonte oceanic domain, characterised by alpine metamorphism under eclogite facies conditions (Compagnoni, 2003). Moreover, jadeitites and omphacitites are also found in Queyras, a typical blueschist facies area located in the External Piemonte Zone (Caron and Saliot, 1969; Harlow et al., 2014). Locating the supply sources of the raw materials used to produce these artefacts (whether from the Monviso or Voltri massifs) and their nature (whether from primary outcrops or secondary deposits) represent important issues, as they might allow for reconstructing Neolithic manufacturing techniques and ancient migratory fluxes and trade routes (Chiarenza and Giustetto, 2010; D'Amico et al., 1992, 1997, 2013; Pétrequin et al., 2017b). Such a goal can be pursued only by comparing the distinctive mineralogical and petrographic features of these tools with those of analogous geological samples of known origin, searching for common traits that may hint the same provenance. Other lithotypes, such as serpentinites, prasinites and chloritites (occasionally also termed as greenstones, due to their hue), were seldom used to produce these tools. However, due to their ubiquitous distribution in the Western Alps, they have limited archaeometric relevance. This study deals with the characterisation of the polished greenstone industry from the archaeological site of Chiomonte, La Maddalena, near Turin, northwestern Italy (Fig. 1a, b). Over 130 stone implements were investigated with a well-established analytical protocol, thus allowing archaeometric considerations.

\section{Materials and methods}

\subsection{Archaeological case study and materials}

The archaeological site of Chiomonte, La Maddalena (The Magdalene), was discovered in 1985, while excavating for the Fréjus highway, and explored by the local Archaeological Superintendence during three campaigns. The site, inhabited from the middle Neolithic until the Medieval period, is positioned in the high-altitude Susa valley (718 $\mathrm{m}$ a.s.l.) at the base of a slope on the left side of the Dora Riparia river (Fig. 1b), sheltered by big boulders that originate from an ancient landslide deposit. The La Maddalena site corresponds to a terraced surface on fluvioglacial deposits close to the Clarea stream, which flows $60-80 \mathrm{~m}$ downstream. The archaeological materials (ceramics and splintered and polished stone) lay directly on landslide and fluvioglacial deposits, showing two separate colluvial layers: (i) a lower, muddy, and sandy level, conserving traces of anthropic activity and (ii) a superficial, gravelly, and pebbly layer, with landslide blocks in the upper portion and strongly muddled-up archaeological goods. An area of about $12500 \mathrm{~m}^{2}$ at the base of the slope was stratigraphically investigated, thus uncovering a significant number of structures and artefacts pertinent to a multiphase settlement dating back to the middle to late $\mathrm{Ne}$ olithic. The importance of the site is due to the frequent relationships that occurred between the end of the fifth millennium BCE to the first half of the fourth millennium BCE with other cultures on the French and Swiss sides of the Western Alps, especially in the high and medium Rhône valley (Padovan, 2017). The polished stone industry of Chiomonte consists of 132 objects, mostly in greenstone, mainly represented by instruments for cutting (i.e. axe heads, with some hatchets and scalpels). All of the different steps of the manufacturing chain are represented, including several tool fragments and/or roughouts. Few are the finished objects, whilst some pebbles are also present. The collection was held in the archaeological museum "La Maddalena - Chiomonte", recently closed due to the construction of the high-speed train line from Turin to Lyon. Since then, it has been transferred to the collection of the Antiquity Museum in Turin.

\subsection{Methods}

All 132 retrieved implements were analysed with a wellestablished protocol, involving archaeological (morphotypological exam) and archaeometric (non-invasive mineralogical and petrographic analyses) methods, aimed at obtaining a statistical screening about their functionality and lithology. Furthermore, a more restricted number of tools, based on their lithotype and mineralogical and petrographic features, was selected for micro-invasive analyses. Although alternative non-destructive approaches have been recently used (e.g. SEM-EDX, energy-dispersive X-ray analyser, to infer the chemistry from the tool's surface and prompt 


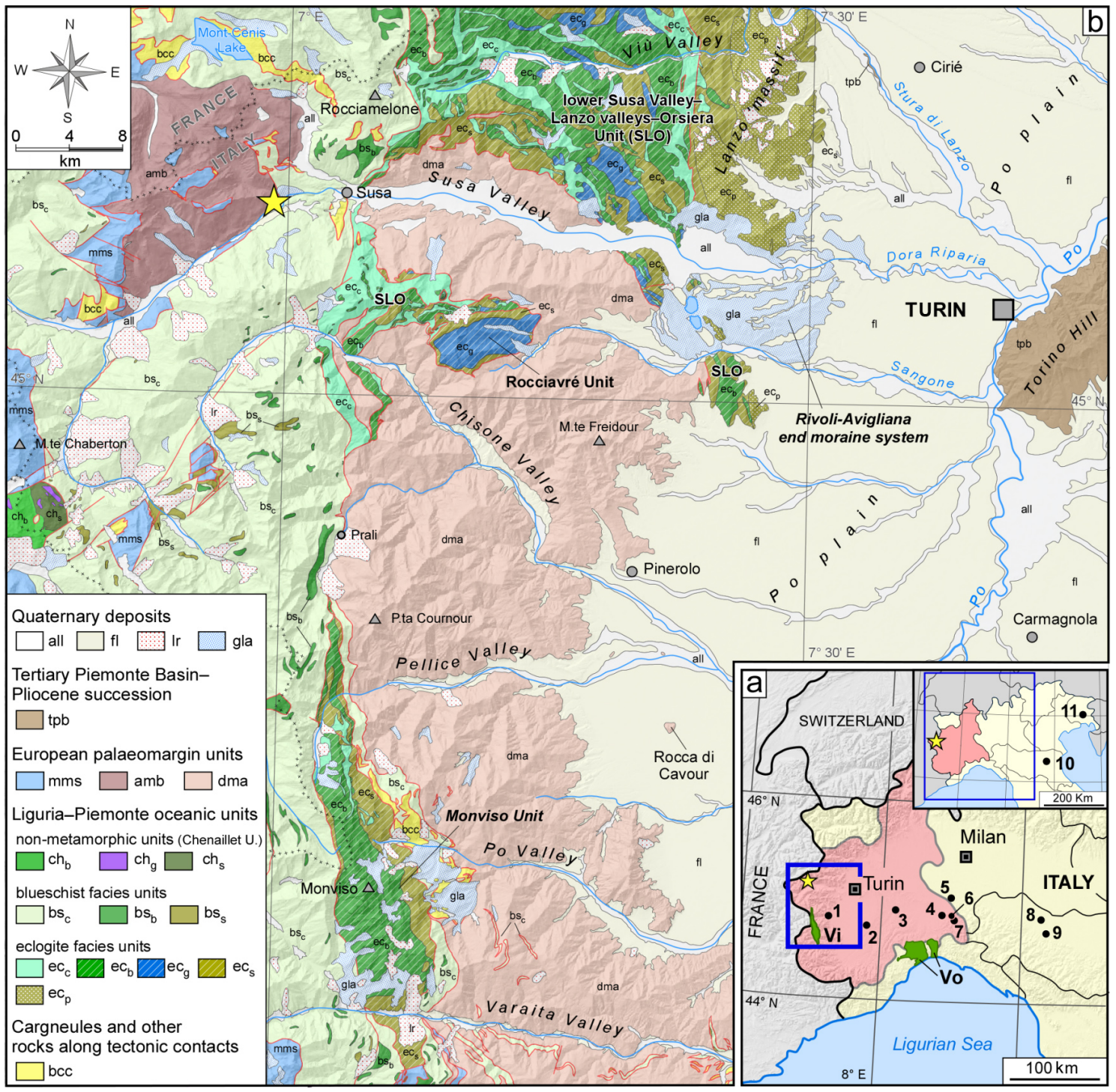

Figure 1. (a) Map of northwestern Italy showing the position of the Chiomonte archaeological site (star) and of the other coeval archaeological sites cited in the text (1 - Rocca di Cavour; 2 - Alba; 3 - Castello di Annone; 4 - Villaromagnano; 5 - Rivanazzano; 6 - Momperone; 7 - Brignano Frascata; 8 - Gaione; 9 - Ponte Ghiara). The position of the Monviso (Vi) and Voltri (Vo) massifs is also shown. The blue rectangle indicates the area of the geological map in (b). The inset shows a simplified map of northern Italy, with an indication of the sites of Chiomonte (star), San Lazzaro di Savena (10) and Sammardenchia (11). (b) Simplified geological map of the Italian side of Cottian and southern Graian Alps (from the Varaita Valley to Viù Valley), showing the position of the archaeological site of Chiomonte (star) and the distribution of the geological units, here considered possible sources for the supply of raw materials (eclogite facies meta-ophiolites of the Liguria-Piemonte oceanic units and alluvial and glacial deposits). Geological boundaries redrawn from Piana et al. (2017) (Italian area), Kerckhove et al. (1980) (French area south of $45^{\circ} \mathrm{N}$ ) and Debelmas (1980) (French area north of $45^{\circ} \mathrm{N}$ ). Quaternary deposits: all - alluvial deposits (Holocene-Present); fl - terraced alluvial and fluvioglacial deposits (Pleistocene-Holocene); lr - landslide, block stream, and rock glacier deposits; gla - glacial deposits. Tertiary Piemonte Basin and Pliocene succession - tpb. European palaeomargin units: Mesozoic meta-sedimentary units - mms; Ambin massif - amb; Dora-Maira unit (pre-Triassic basement rocks and associated meta-sedimentary cover) - dma. Liguria-Piemonte oceanic units: non-metamorphic units (Chenaillet unit; basalt - $\mathrm{ch}_{\mathrm{b}}$; gabbro - chg ; serpentinite and serpentinite breccia $-\mathrm{ch}_{\mathrm{s}}$ ); blueschist facies units (calc-schist $-\mathrm{bs}_{\mathrm{c}}$, with local gneiss intercalations; metabasite $-\mathrm{bs}_{\mathrm{b}}$; serpentinite $-\mathrm{bs}_{\mathrm{s}}$ ); eclogite facies units (Monviso, Rocciavré, lower Susa Valley-Lanzo valley-Orsiera unit, SLO; calc-schist - ec $c_{c}$; metabasite - ec m $_{\mathrm{b}}$; metagabbro - ec g $_{\text {; }}$ serpentinite $-\mathrm{ec}_{\mathrm{s}}$; peridotite of the Lanzo ultramafic massif $-\mathrm{ec}$ ). Cargneules and metasedimentary rocks: main bodies of cargneules - bcc, evaporites and metasedimentary rocks preserved along tectonic contacts. 
gamma activation to obtain their bulk elemental composition without any sampling; Bendô et al., 2014, 2019; Váczi et al., 2019), a micro-invasive protocol was preferred, so as to avoid severe limitations on the area of analysis and dispose of unbiased data. This compromise was counterbalanced by restricting such exams, which include X-ray powder diffraction (22 specimens), optical polarising and scanning electron microscopy (12 specimens, representative of the previous ones; Chiari et al., 1996; Compagnoni et al., 2006; Giustetto et al., 2008), to roughouts and broken or fragmented artefacts in order to preserve the integrity of the few finished tools. Small cores $(10 \mathrm{~mm}$ diameter), at best representative of the rock composition, were extracted with a diamond crown drill and used to prepare powders and $30 \mu \mathrm{m}$ polished thin sections. These analyses were aimed at pointing out typical mineralogical and petrographic "markers", to be compared with those already described in the literature for analogous geological samples of known origin.

X-ray powder diffraction (XRPD) data were collected in the $3-70^{\circ} 2 \theta$ range, using an automated Siemens D-5000 diffractometer with a $\theta / 2 \theta$ set-up using Bragg-Brentano geometry, $\mathrm{CuK} \alpha$ radiation, and a zero-background, flat sample holder. Data were processed with the Diffrac Plus (2005) software (EVA 11,00,3).

Polarising microscopy was performed on a Zeiss WL Pol optical instrument. Scanning electron microscopy (SEM) was performed with a SEM Stereoscan 360, Cambridge Instruments, on carbon-coated thin sections. Chemical characterisation was performed by an EDS Link Pentafet, Oxford Instruments (operating conditions: $50 \mathrm{~s}$ counting time, $15 \mathrm{kV}$ accelerating voltage, $25 \mathrm{~mm}$ working distance, and $300 \mathrm{pA}$ beam current). The collected data were processed with the INCA 200 Microanalysis Suite Software, version 4.08, calibrated to natural mineral standards using the ZAF correction method.

\section{Results}

\subsection{Morpho-typological examination}

The raw processing state and fragmentary conditions of the Chiomonte tools (especially axes and hatchets) allow only preliminary typological considerations, due to difficulties in checking their effective dimensions (length, width and thickness), upon which the existing classifications are based (Pedrotti, 1996). However, the studied tools and roughouts (132 in total, some of which are shown in Fig. 2a) can be classified, based on their functionality and traces of manufacture and use, mostly as implements for cutting (axes, 52\%; hatchets and chisels, $10 \%$ ), with a few classified as being for striking (percussors, $5 \%$ ) or abrading (grindstones and millstones, $3 \%$ ). Some instruments with ornamental or recreational purposes (pendants and taws, 5\%) have also been found. Finally, numerous splinters, unspecified fragments and/or pebbles (22\%), and a few residual samples with no plausible function ( $3 \%$ ) have been found (Fig. 2b). As far as instruments for cutting are concerned, few complete and finished artefacts exist ( 8 out of 82 total), with small to moderate dimensions, whilst the number of roughouts and fragmented tools (probably broken during manufacture and/or after use) is significant (58). Table S1 in the Supplement lists, for each implement, the inventory label(s) and presumed typological function.

\subsection{Density measurements and stereo-microscopy examination}

Density values were determined with a precision balance (weighing each tool in air and in water; Compagnoni et al., 2006) for 119 (out of 132) artefacts by excluding those too small to obtain reliable measurements. All implements were also examined with a stereo-microscope in reflected light, on wet and polished surfaces (if present), in order to evaluate their mineral grain size, heterogeneities and microstructural features. A preliminary lithotype determination was thus achieved (see the Supplement, Table S1).

The density histogram for greenstones (Fig. 3a) shows a sharp distinction between HP metaophiolites sensu stricto (i.e. Na pyroxenites and Na pyroxene and garnet rocks, usually $>3 \mathrm{~g} \mathrm{~cm}^{-3}$ ) and other lithotypes that are similar to the naked eye (i.e. serpentinites and prasinites, with densities usually $<3 \mathrm{~g} \mathrm{~cm}^{-3}$ ). Eclogites show higher densities (mostly between 3.4 and $3.6 \mathrm{~g} \mathrm{~cm}^{-3}$ ), partially overlapping with the slightly lower ones for jadeitites, omphacitites and mixed $\mathrm{Na}$ pyroxenites (varying between 3.2 and $3.5 \mathrm{~g} \mathrm{~cm}^{-3}$ ). The lithotype distribution (Fig. 3b) is rather heterogeneous, with serpentinite as the most abundant rock (25\%). Globally, sensu stricto greenstones represent $50 \%$ of the tools. Among these, mixed Na pyroxenite (almost $24 \%$ ) is the most abundant rock, followed by eclogite (19\%). Jadeitite and omphacitite are scarce ( $2 \%$ and $3 \%$, respectively), as well as garnetbearing omphacitite $(2 \%)$. Based on the average distribution, 22 samples were selected among the roughouts and broken and fragmented tools for micro-invasive analyses (Table 1).

\subsection{X-ray powder diffraction}

With this technique, the mineralogical composition of the 22 selected samples was determined and confirmed their lithotypes. A rough measurement of the reflection intensities for the crystalline phases is also reported, prompting semiquantitative evaluations (Table 2).

A total of 16 samples are made of sensu stricto "greenstones", the rest being related to other less representative (e.g. chloritites and serpentinites) or peculiar lithologies. $\mathrm{Na}$ pyroxene rocks are made of a single pyroxene with a welldefined composition (jadeitite and omphacitite) or two pyroxenes in almost equal amounts (mixed Na pyroxenite) with few or no minor phases. The three main pyroxene reflections, 
R. Giustetto et al.: The Neolithic greenstone industry of Chiomonte (Italy)

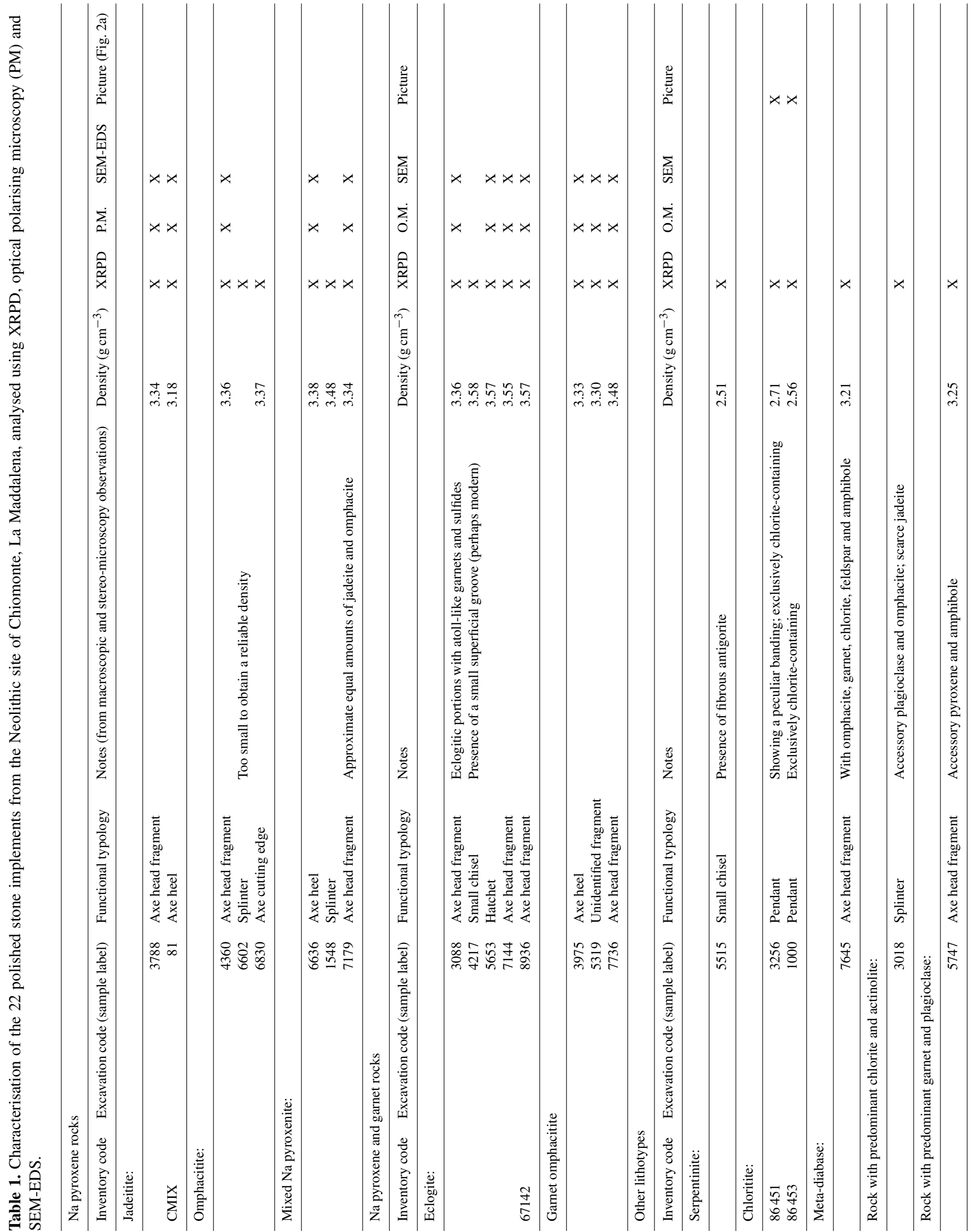




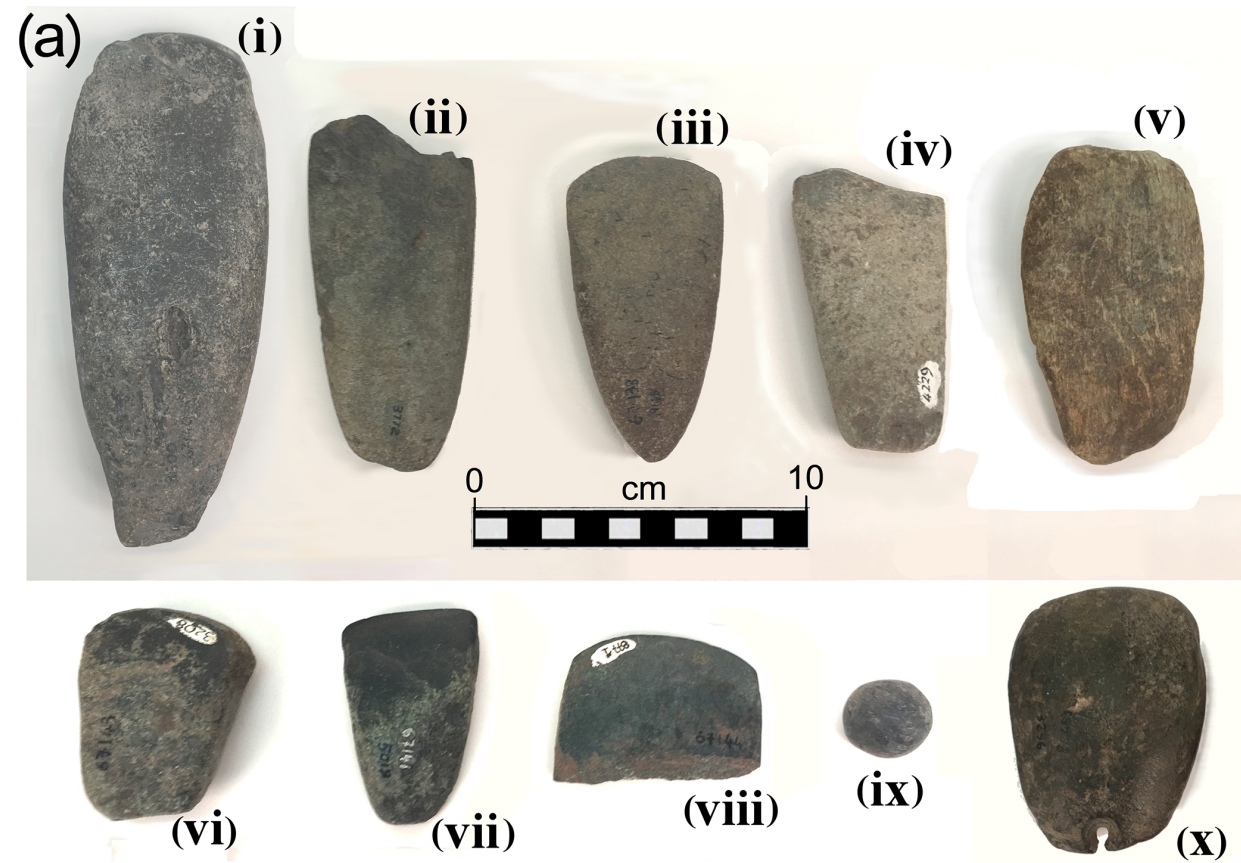

(b) Typological distribution - Chiomonte

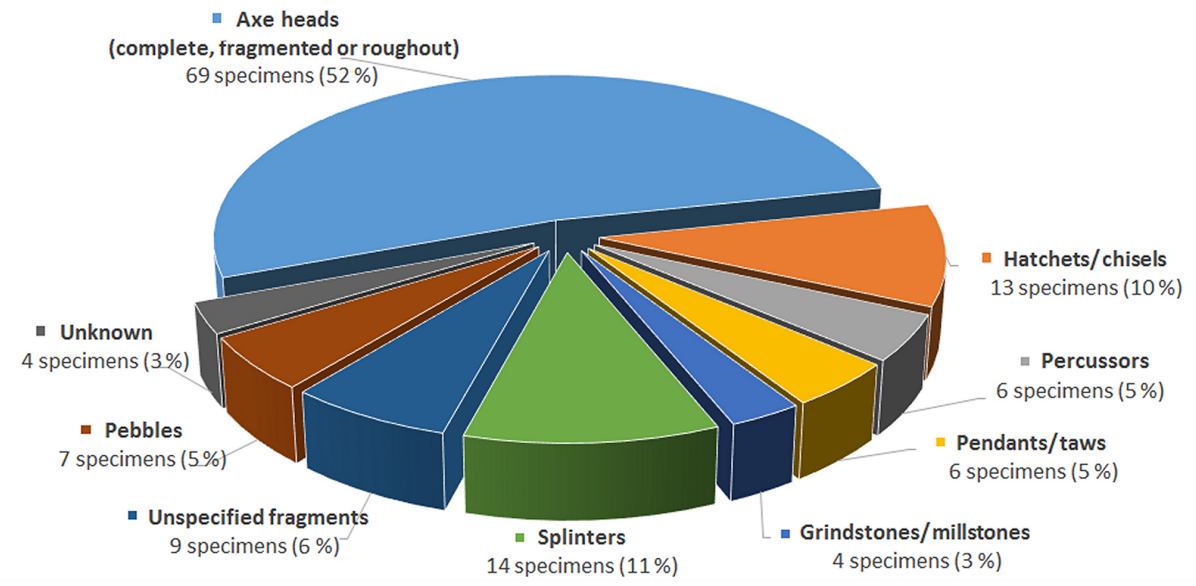

Figure 2. (a) Examples of Neolithic tools from Chiomonte: (i) 67 140/3600 (axe head, serpentinite), (ii) 3772 (axe head, eclogite), (iii) 67 138/4148 (axe head; jadeitite with albite?), (iv) 4229 (axe head, mixed Na pyroxenite, (v) 86 453/1000 (pendant, chloritite; studied with XRPD), (vi) 67 143/3208 (small axe head, mixed Na pyroxenite), (vii) 67 141/5018 (small axe head, mixed Na pyroxenite and eclogite), (viii) 67 144/8771 (axe fragment, mixed Na pyroxenite), (ix) 67 161/5117 (taw, serpentinite) and (x) $86451 / 3256$ (pendant, chloritite; studied with XRPD) (other details are reported in the Supplement Table S1). (b) Diagram reporting the functional distribution of the polished stone tools from the archaeological site of Chiomonte, based on results from morpho-typological studies.

$-221,310$ and 002, are well defined in jadeitite (Fig. 4a) and omphacitite (Fig. 4b), while in mixed Na pyroxenite they are split due to presence of both jadeite and omphacite, each with a complex zoning (Fig. 4c). In Na pyroxene and garnet rocks, the reflections of garnet also appear, which are evident in eclogite (Fig. 4d) but hardly visible in garnet-bearing omphacitite (Table 2). In sample 5747, the reflections of garnet prevail over those of other phases (omphacite, plagioclase and minor clinochlore and amphibole), thus suggesting a peculiar composition.

The chemistry of Na pyroxene solid solutions may be estimated from the inter-planar distance $\left(\mathrm{d}_{\mathrm{hkl}}\right)$ values of their main reflections $(-221,310,002)$. When transferred on the grid proposed by Giustetto et al. (2008) and superposed to the Jd-Q-Ae diagram of Morimoto et al. (1988), these values lead to an average composition affected by a mostly restricted error (Fig. 5a, b and c). 

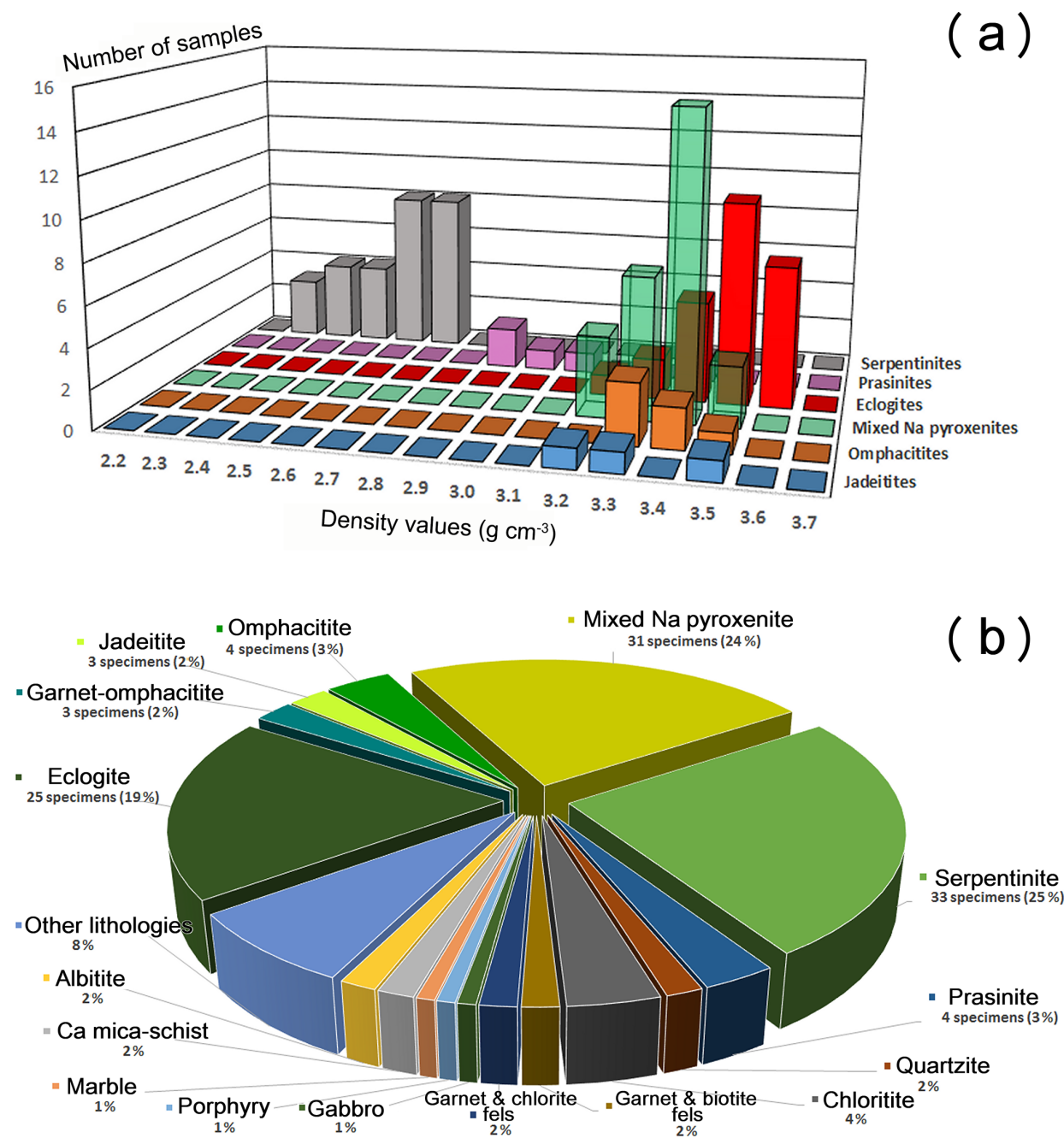

Figure 3. (a) Histogram of density measurements, performed on 119 (out of 132) lithic implements from Chiomonte. (b) Preliminary lithotype distribution of the 132 tools from Chiomonte, obtained by combining stereo-microscopic observations and density measurements.

\subsection{Polarising microscopy and SEM-EDS}

The petrographic approach, despite its micro-destructivity, is fundamental for identifying compositional mineral zoning and micro-structural heterogeneities of these rocks, together with the chronological relationships among different pyroxene (and garnet) generation. Moreover, the petrographic study allows for identifying minor phases undetected by XRPD. All of these features are essential for the comparison between data collected on prehistoric tools and geological specimens of known provenance, in order to trace the origin of the raw materials (Giustetto et al., 2017). A total of 12 thin sections were obtained from as many tools of sensu stricto greenstone already inspected by XRPD:

- five Na pyroxene rocks (two jadeitites, one omphacitite and two mixed Na pyroxenite),
- seven Na pyroxene and garnet rocks (four eclogites and three garnet omphacitites).

The chemistry and zoning of pyroxene and garnet were studied by plotting EDS data in the ternary diagrams of Morimoto et al. (1988) (Fig. 5a, b and c) and of almandine (Alm), spessartine (Sps), grossular (Grs), and pyrope (Prp) (Fig. 6). Table 3 provides the semi-quantitative mineralogical composition obtained for each sample by combining XRPD, polarising microscopy and SEM-EDS. Selected EDS analyses for pyroxene and garnet are reported in the Supplement (Tables $\mathrm{S} 2$ to $\mathrm{S} 20$ ).

\subsubsection{Na pyroxene rocks: jadeitites}

The 3788 axe head fragment is a typical jadeitite with a granoblastic structure and faint foliation, marked by jadeite crystals with a complex zoning that includes greener omphacite domains. Locally, the Jd crystals show "dusty" cores 
Table 2. Mineralogical composition of the 22 polished stone implements (Na pyroxene rocks, Na pyroxene and garnet rocks, and other lithotypes) from the Neolithic site of Chiomonte, La Maddalena, according to XRPD (XXX: very strong reflections; XX: strong reflections; $\mathrm{X}$ : weak reflections; $\mathrm{X}($ ?): dubious).

\begin{tabular}{|c|c|c|c|c|c|c|c|c|c|c|c|c|}
\hline \multirow[b]{2}{*}{ Sample label } & \multicolumn{11}{|c|}{ Minerals } & \multirow[b]{2}{*}{ Notes } \\
\hline & $\begin{array}{l}\frac{0}{0} \\
\frac{ \pm}{0} \\
\frac{0}{0} \\
0\end{array}$ & $\frac{\stackrel{0}{0}}{\frac{\tilde{D}}{\sigma}}$ & & $\begin{array}{l}\frac{0}{8} \\
\frac{0}{3} \\
\frac{1}{2} \\
\frac{1}{2}\end{array}$ & $\begin{array}{l}\frac{0}{0} \\
\frac{0}{0} \\
\text { Ẽ } \\
\text { 元 }\end{array}$ & $\begin{array}{l}\frac{0}{0} \\
\frac{0}{0} \\
\stackrel{0}{\Xi} \\
.0\end{array}$ & $\begin{array}{l}\frac{8}{0} \\
\frac{\pi}{0} \\
\frac{0}{00} \\
\frac{\pi}{D}\end{array}$ & $\begin{array}{l}\stackrel{\Xi}{\Xi} \\
\stackrel{\Xi}{\Xi} \\
\stackrel{\Xi}{\Xi}\end{array}$ & 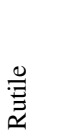 & 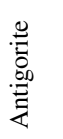 & 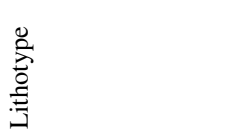 & \\
\hline \multicolumn{13}{|c|}{ Na pyroxene rocks } \\
\hline 3788 & $\mathrm{x}$ & $\mathrm{xxx}$ & & & & & & & & & jadeitite & $\begin{array}{l}\text { shoulders account for scarce presence of om- } \\
\text { phacite }\end{array}$ \\
\hline 81 & & $\mathrm{xxx}$ & & & & & $\mathrm{x}$ & & & & jadeitite & plagioclase is possibly albite \\
\hline 4360 & $\mathrm{xxx}$ & & & & & & & & & & omphacitite & $\begin{array}{l}\text { weak shoulders account for possible presence } \\
\text { of jadeite }\end{array}$ \\
\hline 6602 & $\mathrm{xxx}$ & & & & & & & & & & omphacitite & $\begin{array}{l}\text { weak shoulders account for possible presence } \\
\text { of jadeite }\end{array}$ \\
\hline 6830 & $\mathrm{xxx}$ & & & & & $\mathrm{x}$ & & $\mathrm{x}(?)$ & & & omphacitite & $\begin{array}{l}\text { peak at } 2 \theta=32.53^{\circ} ; d_{\mathrm{hkl}}=2.751 \text {, possible il- } \\
\text { menite }\end{array}$ \\
\hline 6636 & $\mathrm{xxx}$ & $\mathrm{xx}$ & & & & & & & & & mixed Na pyroxene & jadeite reflections less intense than omphacite \\
\hline 1548 & $\mathrm{xx}$ & $\mathrm{xxx}$ & & & & & & & & & $\begin{array}{l}\text { mixed } \mathrm{Na} \text { pyrox- } \\
\text { ene. }\end{array}$ & $\begin{array}{l}\text { reflections not distinct but fringed (zoned py- } \\
\text { roxenes) }\end{array}$ \\
\hline 7179 & $\mathrm{xxx}$ & $\mathrm{xx}$ & & & & & & & & & mixed Na pyroxene & $\begin{array}{l}\text { reflections not distinct but fringed (zoned py- } \\
\text { roxenes) }\end{array}$ \\
\hline \multicolumn{13}{|c|}{ Na pyroxene and garnet rocks } \\
\hline 3088 & $\mathrm{xxx}$ & & $\mathrm{xxx}$ & & & & & & & & eclogite & garnet is mainly almandine and pyrope \\
\hline 4217 & $\mathrm{xxx}$ & $\mathrm{x}(?)$ & $\mathrm{xxx}$ & & & & & & & & eclogite & $\begin{array}{l}\text { weak shoulders account for possible presence } \\
\text { of jadeite }\end{array}$ \\
\hline 5653 & $\mathrm{xxx}$ & $\mathrm{x}(?)$ & $\mathrm{xxx}$ & & & $\mathrm{x}$ & & & & & eclogite & $\begin{array}{l}\text { weak shoulders account for possible presence } \\
\text { of jadeite }\end{array}$ \\
\hline 7144 & $\mathrm{xxx}$ & $\mathrm{x}(?)$ & $\mathrm{xxx}$ & & & & & & $\mathrm{x}(?)$ & & eclogite & $\begin{array}{l}\text { weak shoulders account for possible presence } \\
\text { of jadeite }\end{array}$ \\
\hline 8936 & $\mathrm{xxx}$ & & $\mathrm{xxx}$ & & & & & & & & eclogite & garnet is mainly almandine \\
\hline 3975 & $\mathrm{xxx}$ & & $\mathrm{x}(?)$ & & & & & & & & garnet omphacitite & $\begin{array}{l}\text { weak shoulders account for feasible presence of } \\
\text { aegirine }\end{array}$ \\
\hline 5319 & $\mathrm{xxx}$ & & $\mathrm{x}(?)$ & & & & & & & & garnet omphacitite & $\begin{array}{l}\text { splitting of omphacite peaks suggests pyroxene } \\
\text { zoning }\end{array}$ \\
\hline 7736 & $\mathrm{xxx}$ & & $\mathrm{x}$ & & & $\mathrm{x}$ & & & & & garnet omphacitite & $\begin{array}{l}\text { splitting of omphacite peaks suggests pyroxene } \\
\text { zoning }\end{array}$ \\
\hline \multicolumn{13}{|c|}{ Other lithotypes } \\
\hline 5515 & & & & & & & & & & $\mathrm{xxx}$ & serpentinite & antigorite is the only phase \\
\hline 3256 & & & & & & $\mathrm{xxx}$ & & & & & chloritite & clinochlore is the only detectable phase \\
\hline 1000 & & & & & & $\mathrm{xxx}$ & & & & & chloritite & clinochlore is the only detectable phase \\
\hline 7645 & $\mathrm{xx}$ & & $\mathrm{xx}$ & & $\mathrm{xx}$ & $\mathrm{xx}$ & $\mathrm{xx}$ & & & & meta-diabase & plagioclase is possibly albite \\
\hline 3018 & $\mathrm{xx}$ & $\mathrm{x}(?)$ & $\mathrm{x}(?)$ & & $\mathrm{xxx}$ & $\mathrm{xxx}$ & $\mathrm{xx}$ & & & & $\begin{array}{l}\text { rock rich in chlorite } \\
\text { and actinolite }\end{array}$ & $\begin{array}{l}\text { unidentified reflection at } d=2.675 \AA \text {; possible } \\
\text { garnet }\end{array}$ \\
\hline 5747 & $\mathrm{x}$ & & $\mathrm{xxx}$ & $\mathrm{xx}$ & & $\mathrm{xx}$ & $\mathrm{xx}$ & & & & $\begin{array}{l}\text { rock rich in gar- } \\
\text { net and plagioclase } \\
\text { (omphacite- } \\
\text { garnetite?) }\end{array}$ & $\begin{array}{l}\text { garnet spessartine; splitting of omphacite peaks } \\
\text { (zoning) }\end{array}$ \\
\hline
\end{tabular}

or small, iso-oriented linear exsolutions of a omphacitic nature (Fig. 7a), together with scarce opaque ores. The SEMEDS analyses proved that these omphacitic domains have a rather low Ae content $(<20 \%$; Table S2). Blue-green amphibole coupled with apatite, titanite, zircon and biotite occur as minor or accessory phases. The other sample (CMIX/81; axe heel) is marked by crumbled Jd crystals (hundreds of micrometres across), partly retrogressed with a "dusky" aspect (Fig. 7b), and albite. SEM-EDS investigations indicated that the jadeitic matrix includes tiny and irregular omphacite ex- 

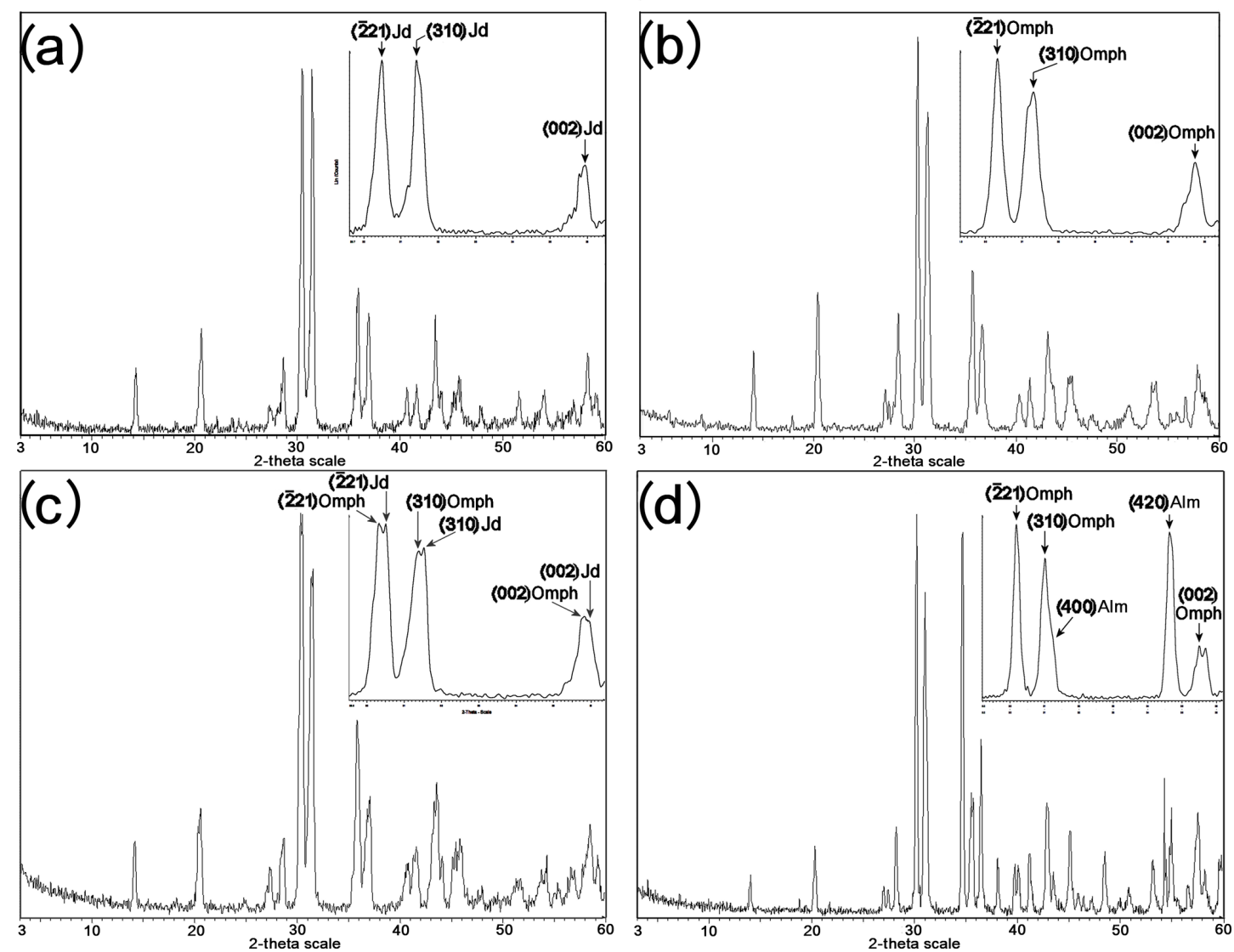

Figure 4. X-ray powder diffraction patterns of selected tools from Chiomonte. In jadeitite (a: 3788) and omphacitite (b: 6602), the characteristic reflections of clinopyroxenes (-221, 310 and 002; see the magnifications in the upper right corners of each panel) are sharp and mostly singular. In mixed Na pyroxenite (c: 7179), the coexistence of both jadeite and omphacite in almost equal amounts splits them into two partially superposed peaks. In eclogite (d: 67 142/8936), reflections of garnet (i.e. almandine) also appear. (Jd, jadeite; Omph, omphacite; Alm, almandine; $\mathrm{Cu}-K \alpha$ radiation).

solutions, with no (or little) Ae. White mica (paragonite) also occurs, together with clinozoisite, nepheline and titanite.

\subsubsection{Na pyroxene rocks: omphacitites}

The studied artefact (4360; axe head fragment) is quite homogenous and fine-grained, with an incipient mylonitic microstructure. Small green and zoned omphacite crystals $(\approx$ $50 \mu \mathrm{m})$ locally have tiny, iso-oriented and darker inclusions (Fig. 8a). The SEM images show a complex pyroxene zoning, with older, richer $\mathrm{Ca} / \mathrm{Mg}$ domains (brighter in backscattered electrons, BSEs) being surrounded by a younger, richer $\mathrm{Na} / \mathrm{Al}$ matrix (darker; Fig. 8b). Spot analyses clearly indicate an omphacitic composition, with a wide range of $\mathrm{Ae}$ content (10\% up to $40 \%$; Table S4). Zircon is the only accessory phase.

\subsubsection{Na pyroxene rocks: mixed Na pyroxenites}

The two studied specimens are similar. The 6636 axe heel exhibits an evident foliation, defined by the alignment of abun- dant rutile, commonly forming aggregates. The very finegrained pyroxene matrix shows a complex zoning, appreciable only at high magnifications, with a dual distribution of colourless jadeite and greenish omphacite (Fig. 9a). At SEM, such a zoning shows, in some areas, the presence of darker jadeite "relics", corroded by a younger omphacite (Fig. 9b).

The 7179 axe head fragment is also fine-grained, though some stumpy pyroxene crystals locally occur, commonly wrapped out by shear zones marked by the preferred orientation of finer-grained, iso-dimensional crystals. The only accessory minerals are rutile and zircon. The distribution of EDS spot analyses covers an almost continuous range between the jadeite and omphacite fields. The aegirine content is usually less than $20 \%$ (Table S6).

\subsubsection{Na pyroxene and garnet rocks: eclogites}

Three (out of the four) analysed eclogites (3088, 5653, and $67142 / 8936)$ show fine-grained to very fine-grained omphacite matrices, commonly with a mylonitic structure. When observed at the polarising microscope, pyroxenes 
(a)

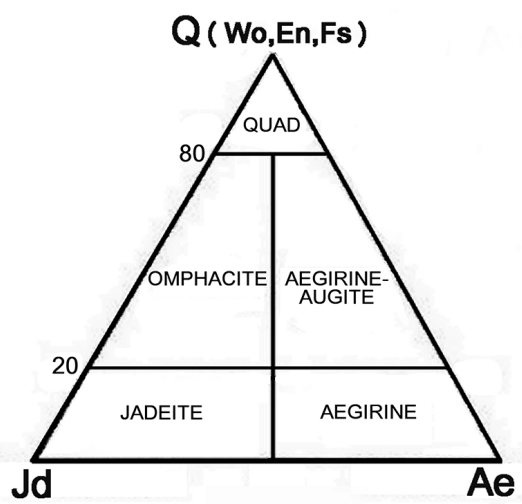

(b)

\section{Na PYROXENE ROCKS}

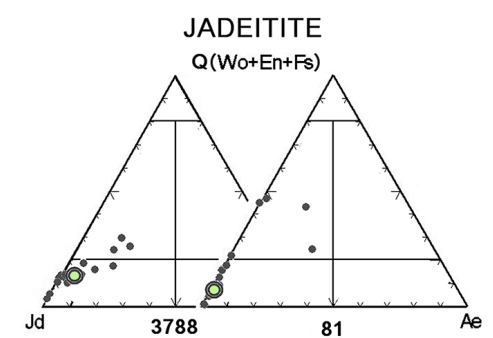

OMPHACITITE
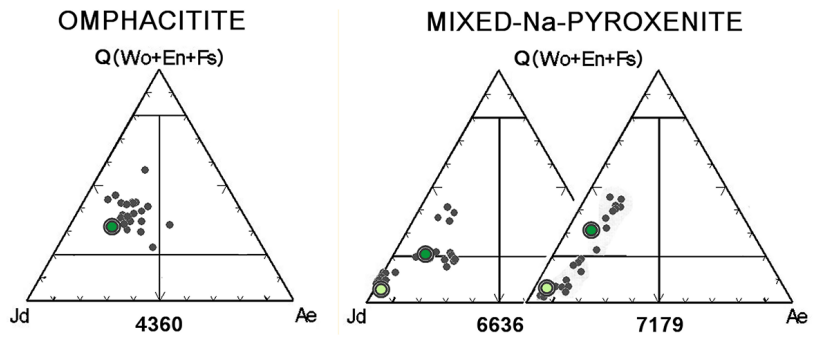

(c)

Na PYROXENE AND GARNET ROCKS
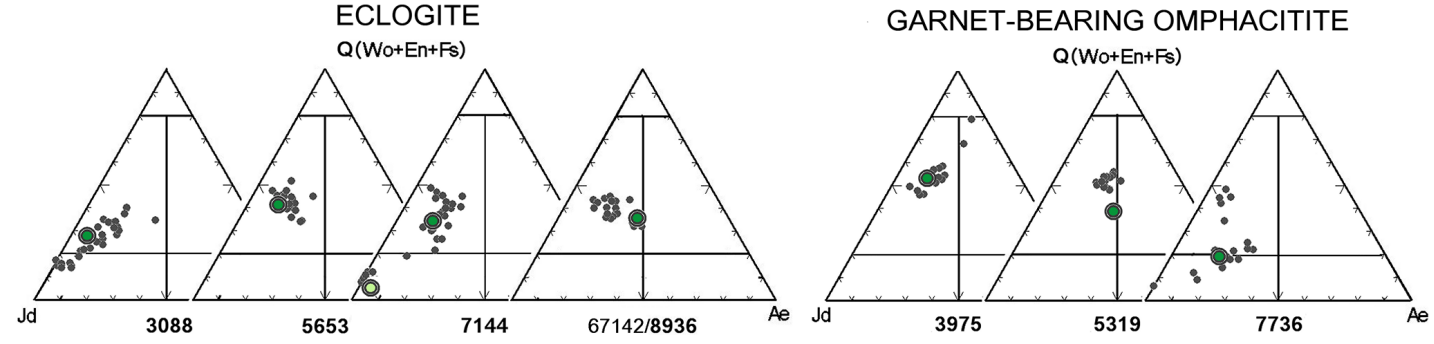

Figure 5. (a) Pyroxene classification diagram proposed by Morimoto et al. (1988), (a) reporting the compositional variation in clinopyroxenes in the Chiomonte tools, (b) Na pyroxene rocks (five specimens), and (c) Na pyroxene and garnet rocks (seven specimens). The bigger dots indicate the average composition of jadeite (light green) and omphacite (dark green) solid solutions, estimated by plotting the $d_{\mathrm{hkl}}$ values of the three characteristic clinopyroxenes reflections (-221, 310 and 002) on the compositional grid of Giustetto et al. (2008).

show a strong zoning, their colours varying from pale to deep green (Fig. 10a). The EDS data confirm this heterogeneity, the related spot analyses being scattered in the omphacite field (Wo, En and $\mathrm{Fs}_{20-50}$ with $\mathrm{Ae}_{10-40}$; Tables S7, S9 and S13). Jadeite is rare only appearing in sample 3088, where small domains of impure Jd, including small "blebs" of exsolved omphacite, are surrounded by an omphacite matrix. Locally, pyroxene crystals show a peculiar yellowish to blue-green pleochroism. A foliation is evident, marked by the abundant rutile (or pyroxene) crystals. Garnet $(\approx 100 \mu \mathrm{m}$ across) forms packed aggregates and shows a typical atolllike aspect; a greener pyroxene is locally observed inside the atoll (Fig. 10a, b). The garnet chemistry is quite constant, with higher Alm and Sps content (70\%-80\%) and minor pyrope $(20 \%-30 \%)$ and grossular $(<10 \%$; Tables S8, S10 and S14). Occasionally, retrogression zones are observed con- verting both omphacite and garnet into green amphibole. White mica, ilmenite, (rare) sulfides and apatite occur as minor or accessory phases.

The last sample (7144; axe head fragment) differs from the others due to the larger pyroxene grain size (hundreds of micrometres across), including both omphacite and jadeite. Fractured garnet crystals, with no atoll-like habit, form scattered aggregates; large and scattered rutile crystals (hundreds of $\mu \mathrm{m}$ across) occur as an accessory phase (Fig. 10c). SEMEDS analyses showed that relict Jd crystals, including tiny exsolved omphacitic blebs, are corroded by younger zoned omphacite (Fig. 10d). Jadeite is rather pure $\left(\approx \mathrm{Jd}_{90}\right)$, with no or very low $\mathrm{Fe}$ content. The distribution of omphacite analyses is quite scattered $\left(\mathrm{Ae}_{10-20}\right)$, confirming its marked zoning. Garnets are almandine (Alm-Sps80) with minor amounts 
Table 3. Mineralogical composition (vol \%) of 12 polished stone implements in HP meta-ophiolites (five Na pyroxene rocks and seven Na pyroxene and garnet rocks) from the archaeological site of Chiomonte, La Maddalena, obtained by combining X-ray powder diffraction, polarising microscopy and SEM-EDS on thin sections. Legend: $\bigcirc<5 \%, \cdot 5 \%-20 \%, \bullet 20 \%-60 \%, \mathbf{\square}>60 \%$.

\begin{tabular}{|c|c|c|c|c|c|c|c|c|c|c|c|c|c|c|c|c|c|}
\hline \multirow[b]{2}{*}{ Sample label } & \multicolumn{16}{|c|}{ Minerals } & \multirow[b]{2}{*}{ Notes } \\
\hline & 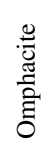 & 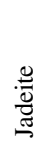 & 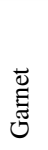 & 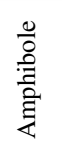 & $\begin{array}{l}\stackrel{0}{0} \\
\frac{9}{0} \\
N\end{array}$ & 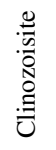 & 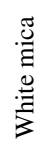 & .气 & 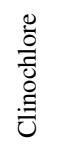 & $\begin{array}{l}\frac{\mathscr{g}}{0} \\
\frac{\pi}{0} \\
\frac{\pi}{00} \\
\frac{\pi}{2}\end{array}$ & 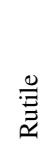 & 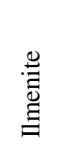 & 总 & 芫 & 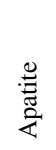 & $\frac{\mathscr{d}}{\frac{\mathscr{E}}{E}}$ & \\
\hline \multicolumn{18}{|c|}{ Na pyroxene rocks } \\
\hline \multicolumn{18}{|l|}{ Jadeitites } \\
\hline $\begin{array}{l}3788 \\
81\end{array}$ & $\dot{0}$ & $\mathbf{a}$ & & & $\bigcirc$ & $\bigcirc$ & $\cdot$ & $\bigcirc$ & & $\cdot$ & & & $\bigcirc$ & $\bigcirc$ & $\bigcirc$ & & $\begin{array}{l}\text { Presence of biotite is dubious } \\
\text { White mica is paragonite; coarse grained }\end{array}$ \\
\hline \multicolumn{18}{|l|}{ Omphacitites } \\
\hline 4360 & $\mathbf{\square}$ & & & & & & & & & & & & & $\bigcirc$ & & & Fine-grained; mylonitic structure \\
\hline \multicolumn{18}{|c|}{ Mixed Na pyroxenites } \\
\hline $\begin{array}{l}6636 \\
7179 \\
\end{array}$ & $\mathbf{0}$ & $\bullet$ & & & & & & & & & $\dot{0}$ & & & $\bigcirc$ & 0 & & Foliation marked by abundant rutile \\
\hline \multicolumn{18}{|c|}{ Na pyroxene and garnet rocks } \\
\hline \multicolumn{18}{|l|}{ Eclogites } \\
\hline $\begin{array}{l}3088 \\
5653 \\
7144 \\
8936\end{array}$ & $\mathbf{\square}$ & ○ & $\begin{array}{l}\bullet \\
\bullet \\
\bullet\end{array}$ & $\bigcirc$ & & & $\bigcirc$ & & $\bigcirc$ & & $\begin{array}{l}\bigcirc \\
\bigcirc \\
\bullet\end{array}$ & $\bigcirc$ & & $\bigcirc$ & $\bigcirc$ & & $\begin{array}{l}\text { Jadeite undetected at polarising microscope } \\
\text { Atoll-like garnets } \\
\text { Jadeite shows small omphacitic exsolutions } \\
\text { Atoll-like garnets in rounded aggregates }\end{array}$ \\
\hline \multicolumn{18}{|c|}{ Garnet omphacitites } \\
\hline $\begin{array}{l}3975 \\
5319 \\
7736\end{array}$ & $\mathbf{\square}$ & & $\stackrel{\bigcirc}{\bigcirc}$ & & & & & & & & $\bigcirc$ & $\bigcirc$ & $\bigcirc$ & & $\bigcirc$ & $\bigcirc$ & $\begin{array}{l}\text { Clinopyroxene has intense green colour } \\
\text { Jadeite younger than omphacite }\end{array}$ \\
\hline
\end{tabular}

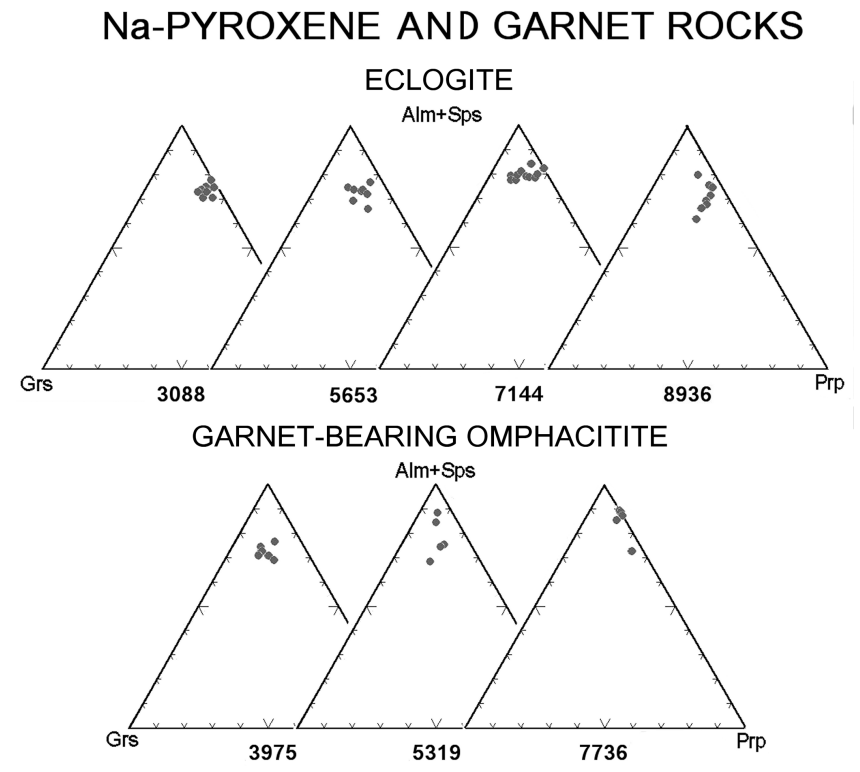

Figure 6. Compositional variation in garnet, plotted in the diagram as almandine (Alm), spessartine (Sps), grossular (Grs), and pyrope (Prp) in Na pyroxene and garnet rocks (seven specimens). of pyrope (around 10\%-20\%) and grossular $(<10 \%$; Tables S11 and S12).

\subsubsection{Na pyroxene and garnet rocks: garnet omphacitites}

All findings of this lithology, a broken axe heel (3975) and two fragments $(5319,7736)$, were analysed. The 3975 sample has a granoblastic structure with mylonitic portions, in which porphyroclasts (hundreds of micrometres across) of a relict magmatic pyroxene exhibit dusky cores and contain deformed ilmenite inclusions (Fig. 11a). The matrix, which is rather homogeneous, has an omphacitic composition, with $\mathrm{Ae}_{10-20}$ (Table S15). In the mylonitic domains, a moderate zoning occurs with scattered spots in the aegirine-augite field. Single, fractured Alm- and Sps-rich (70\%-80\%) garnets with relict appearance, possibly developed after the mylonitic fabric, occasionally overgrow the porphyroclasts. Pyrite, rutile and ilmenite are the only accessory phases. In sample 5319, the microstructure is isotropic, with fragmented and irregularly shaped omphacite crystals (hundreds of $\mu \mathrm{m}$ wide) having a rather homogeneous chemistry. Garnet is scarce and fractured. Apatite and titanite are accessory phases. In 7736, the fine-grained pyroxene matrix shows co- 


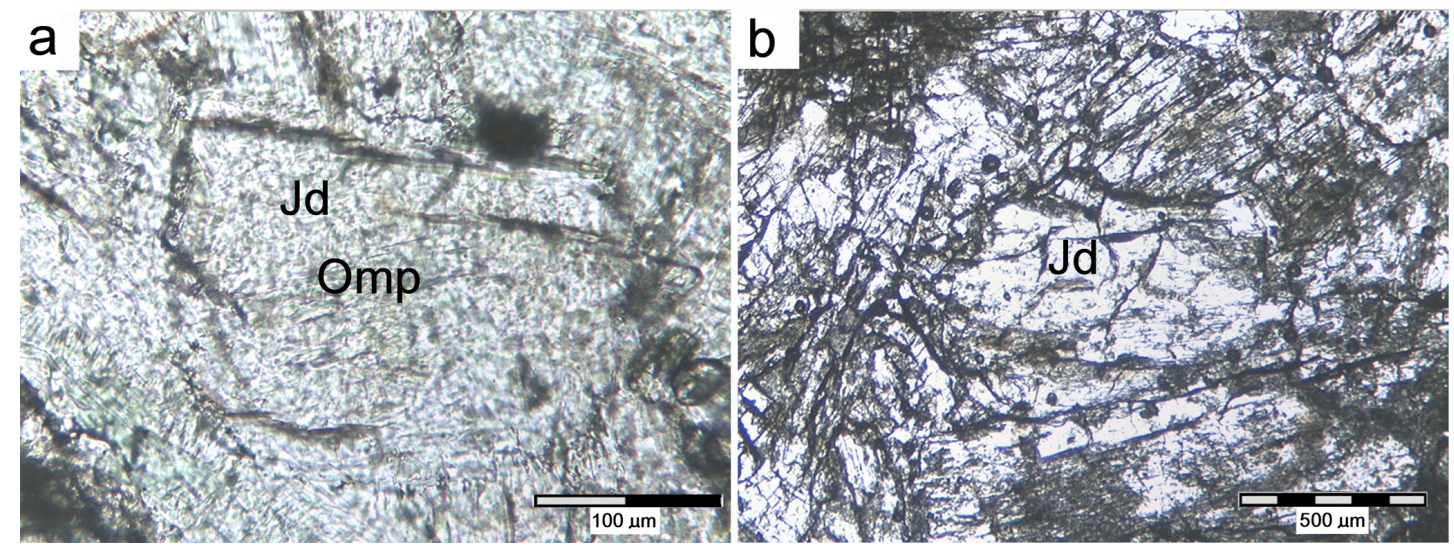

Figure 7. Photomicrographs of jadeitite: (a) jadeite granoblast (Jd), including tiny linear-oriented exsolutions of omphacite (Omp) in the core (3788, plane-polarised light, PPL), and a (b) partly retrogressed jadeite (Jd) matrix, including crumbled crystals (hundreds of micrometres across) intertwined with dusky portions (CMIX/81, PPL).
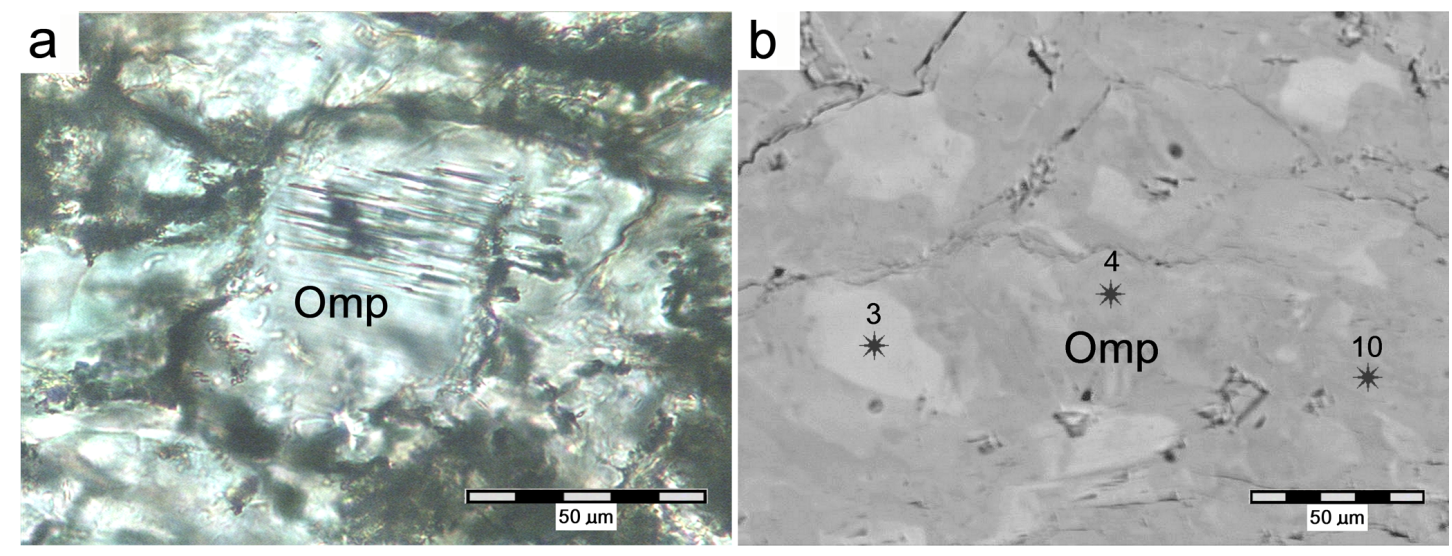

Figure 8. Photomicrographs of omphacitite: (a) pyroxene matrix, in which small omphacite crystals (Omp) that are green in colour and typically zoned show tiny, darker and similarly oriented inclusions in their core (4360, PPL). (b) Complex zoning of pyroxenes: a heterogeneous, darker matrix (richer in $\mathrm{Na}$ and $\mathrm{Al}$ ) including small, lighter domains that are richer in $\mathrm{Ca}$ and $\mathrm{Mg}$ (4360, SEM image, BSE) the numbered stars indicate the spots in which EDS analyses were collected (see Table S4).

existence of both jadeitic and omphacitic domains, with complex mutual relationships. Locally, omphacite seems older than jadeite because it appears in the core of larger crystals (Fig. 11b), in opposition to what has been observed elsewhere (e.g. in 6636 and 7144; Sect. 3.4.3 and 3.4.4). The scattered distribution of EDS analyses confirms the observed zoning, with Ae up to $30 \%$. Scarce and isolated garnets are rich in Alm-Sps (up to $90 \%)$ and poor in Grs $(<5 \%$; Tables S19 and S20). Rutile and interstitial ilmenite occur as accessory phases.

\section{Discussion}

\subsection{Mineralogical and petrographic considerations and provenance issues}

In the Chiomonte lithic industry, the fraction made of sensu stricto greenstones (Na pyroxene rocks and Na pyroxene and garnet rocks) is large (around 50\%) though less conspicuous than elsewhere (e.g. in Brignano Frascata; Giustetto et al., 2017). Serpentinites are quite abundant. This is an uncommon occurrence rarely observed in other sites (e.g. Villaromagnano; Giustetto et al., 2017) and may suggest a certain scarceness of HP greenstones in the areas surveyed for the retrieval of raw materials. Such a possibility has been suggested by Mancusi (2016) and contextualised by D'Amico (2012), who pointed out the scarcity of these tougher lithotypes in the northern Monviso massif (close to the inspected site; Fig. 1b). An alternative explanation might 


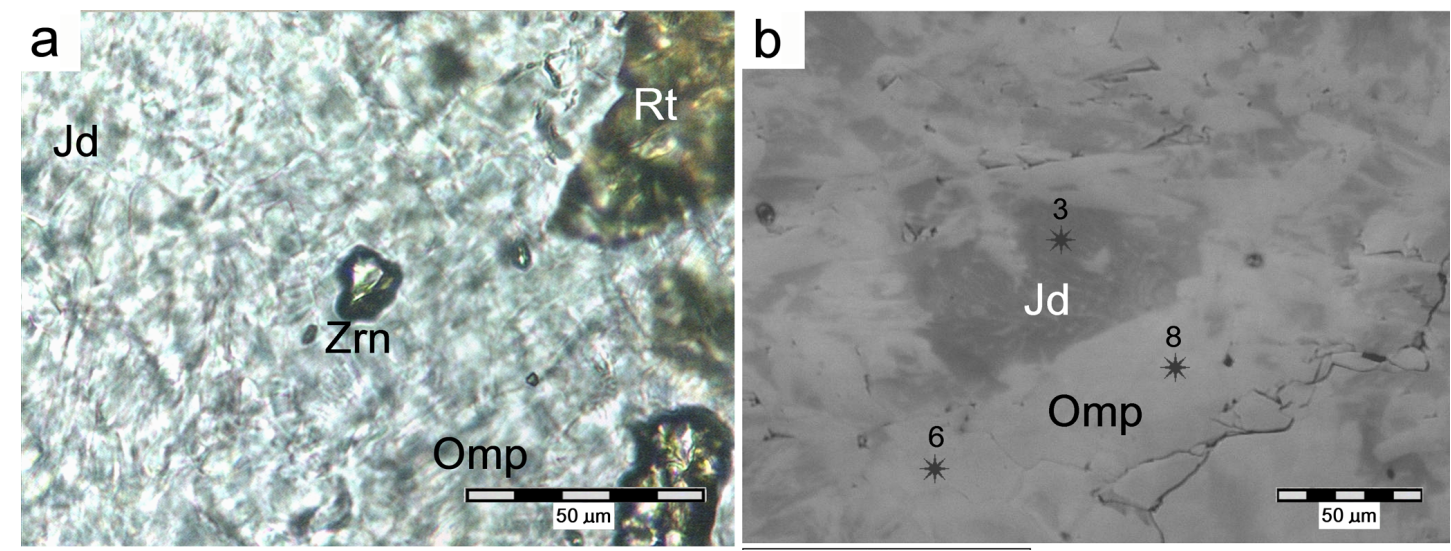

Figure 9. Photomicrographs of mixed Na pyroxenite: (a) small zircon (Zrn) and rutile (Rt) in a matrix of pyroxenes (Jd; Omp), whose zoning is appreciated only at high magnification $(6636$, PPL). (b) The complex zoning of pyroxenes is evident: small and "relict" jadeite crystals (Jd) are surrounded by a younger omphacite matrix (Omp), commonly slipping inside and partly corroding them (6636, SEM image, BSE; the numbered stars indicate the spots in which EDS analyses were collected; see Table S5).

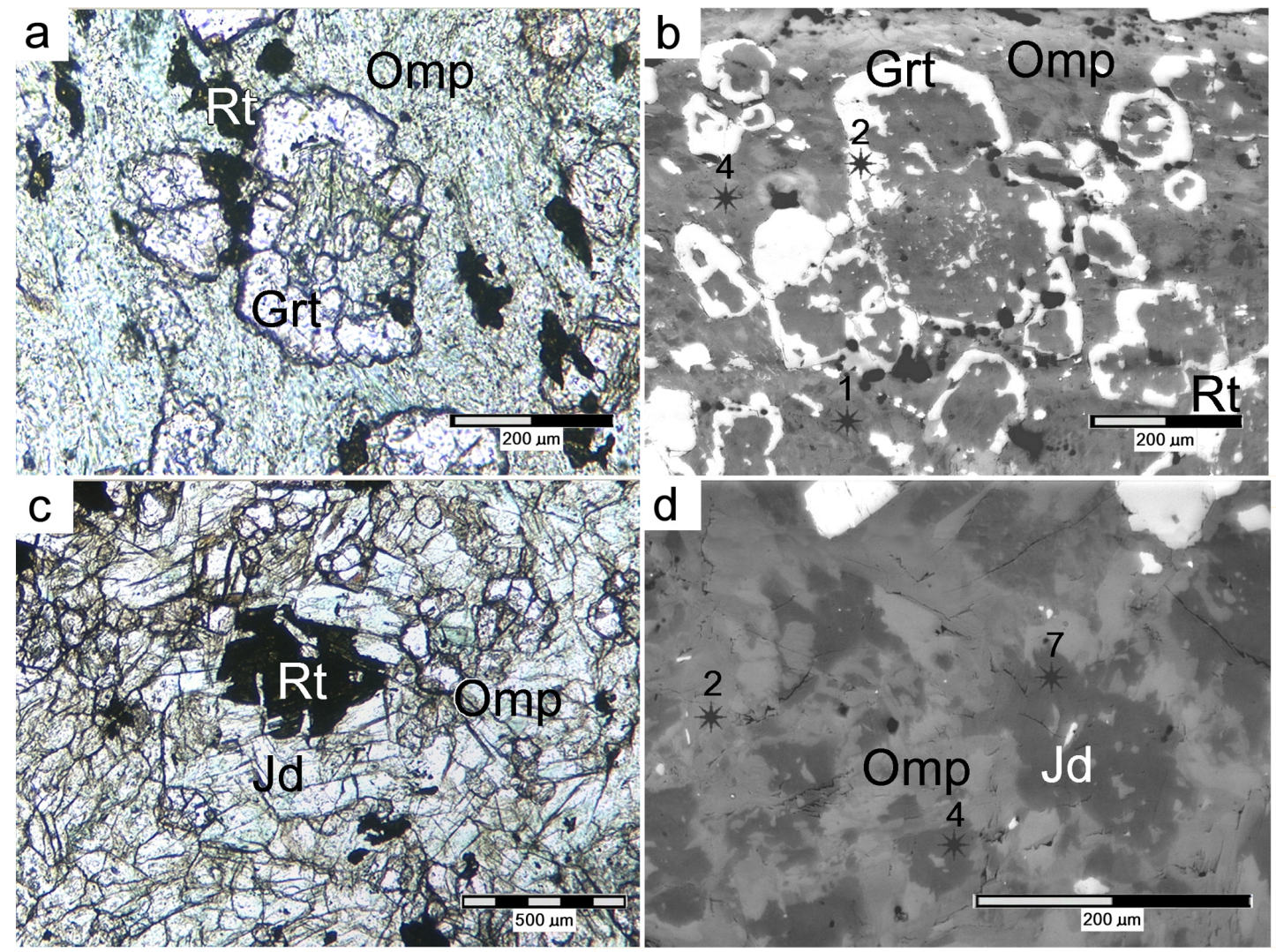

Figure 10. Photomicrographs of eclogite: $(\mathbf{a}, \mathbf{b})$ fractured garnet (Grt), with an atoll-like habit, forms aggregates included in a matrix consisting of mylonitic omphacite (Omp) and occasionally contoured by (brown) rutile (Rt) (67 142/8936, PPL; 3088, SEM image, BSE), the numbered stars indicate the spots in which EDS analyses were collected (see Table S13 for pyroxenes, i.e., analytical spots nos. 1 and 4, and S14 for garnet, i.e., analytical spot no. 2). (c) An admixture of sub-millimetric, idioblastic crystals of jadeitic (light green; Jd) and omphacitic (dark green; Omp) pyroxenes, with scarce garnet. In the middle there is a large rutile aggregate (Rt) (7144, PPL). (d) Restricted jadeite domains (darker) with a relict appearance, including small blebs of exsolved omphacite, are surrounded and crossed by an omphacitic matrix, showing a complex zoning (enhanced by the various shades of grey) (7144, SEM image, BSE). 


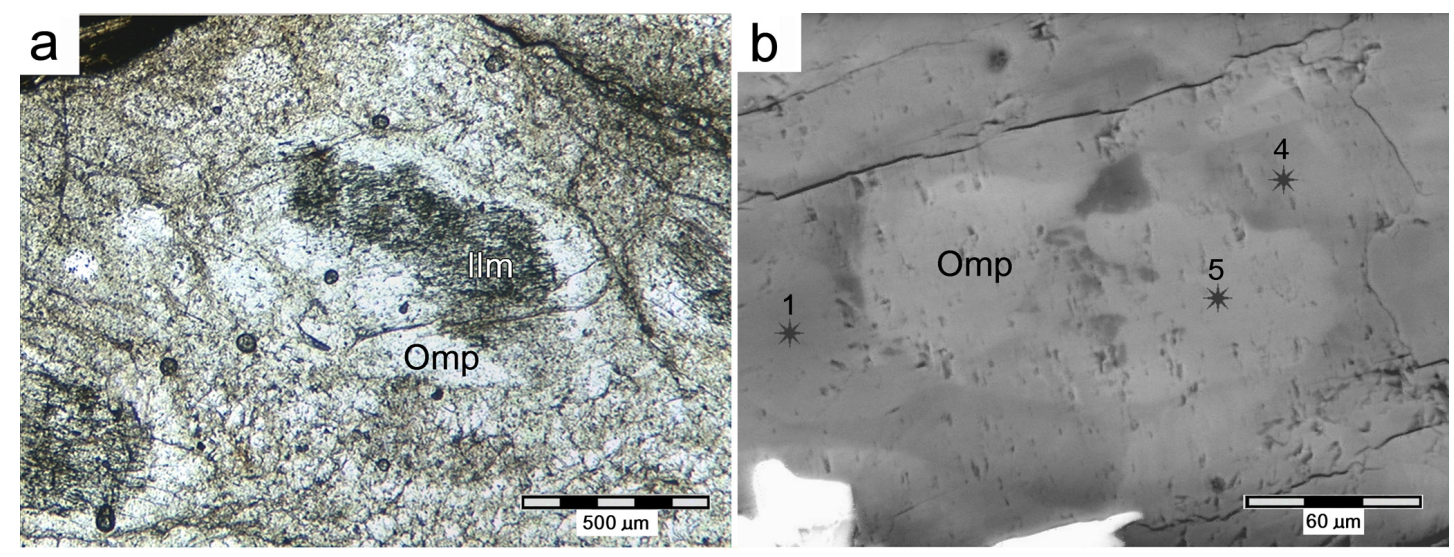

Figure 11. Photomicrographs of garnet omphacitite: (a) porphyroclast of an omphacitic pyroxene (Omp), which shows a dusky core with tiny inclusions of ilmenite (Ilm) (3975, PPL). (b) An unusual zoning for pyroxenes, in which an older omphacitic core (light grey; Omp) is surrounded by a darker rim, richer in $\mathrm{Na}$ and $\mathrm{Al}$ (7736, SEM image, BSE); the numbered stars indicate the spots in which EDS analyses were collected (see Table S19).

be a reduced skill of the local gatherers in tracing those rocks likely to produce better tools. A further oddity in Chiomonte is represented by the assorted fraction of tools made of rocks other than greenstones $(25 \%$, including quartzite and marble, hardly found in other sites), which may further support the inference about the local scarcity of more suitable lithotypes.

$\mathrm{Na}$ pyroxene rocks prevail on $\mathrm{Na}$ pyroxene and garnet rocks (29 vs. $21 \%$ ). Such a trend, though locally seen elsewhere (e.g. Brignano Frascata; Giustetto et al., 2017), is the opposite to what has been observed at most sites (i.e. Alba, Castello di Annone, Gaione, Ponte Ghiara, Rivanazzano, Rocca di Cavour, Sammardenchia and San Lazzaro di Savena; Mannoni and Starnini, 1994; D'Amico et al., 1995, 1997, 2013; D'Amico and Ghedini, 1996; D'Amico and Starnini, 2000, 2012b; Andò, 1998; Bernabò Brea et al., 2000; Borgogno, 2000; Giustetto et al., 2016), in which eclogites dominate, even reaching $66 \%$. Na pyroxene rocks (with mixed $\mathrm{Na}$ pyroxenite being the prevailing rock) are quite abundant with respect to other sites (e.g. Sammardenchia and Rivanazzano), where these jades are $<10 \%$.

From a mineralogical and petrographic point of view, accurate comparison can be done between the Chiomonte tools and those from other coeval sites. Besides, the same data can also be related to analogous geologic material of known provenance, in order to infer analogies or differences and retrieve information about the location of the raw material supply sources. Of course, the reliability of such a survey increases if samples analysed with analogous protocols are compared. This is the reason why, in the following, studies that followed analytical procedures similar to those adopted here (e.g. D'Amico, 2012; Giustetto et al., 2016, 2018) will be taken into account more than others that were based on different approaches (i.e. visual appearance to the naked eye or non-invasive analytical methods, such as spectroradiom- etry; Errera et al., 2012; Pétrequin and Errera, 2017). The latter studies, although providing databases with hundreds of entries (Pétrequin et al., 2012a), offer less reliable mineralogical and petrographic information. Also, it is known that, on average, jadeitites, omphacitites and mixed Na pyroxenites are hard to discriminate with no instrumental support (XRPD, at least) and virtually indistinguishable using visual methods alone (D'Amico, 2012). Similar difficulties arise for eclogites, their garnet often being fine grained (especially in greenstone tools). Moreover, eclogites are hardly recognisable from omphacitites with spectroradiometry, their spectra not being distinctive enough (Errera et al., 2012; Pétrequin et al., 2012a; Pétrequin and Errera, 2017). From this perspective, the high number of roughouts and broken implements becomes an important issue, as micro-invasive mineralogical and petrographic analyses might be restricted to these "unfinished" or incomplete tools, which are seen as more "expendable" than their complete counterparts. This might allow the detection of distinctive (albeit not easily traceable) markers, essential to provide hints about a possible provenance, which would hardly be attainable otherwise.

A remarkable feature of the Chiomonte greenstone tools concerns the scarcity of white mica(s), almost absent in all studied samples (with the exception of CMIX/81, in which paragonite occurs in moderate amounts), albeit regularly detected (by XRPD and SEM-EDS) in tools from the sites of southern and southeastern Piedmont (Castello d'Annone, Brignano Frascata, Momperone and Villaromagnano; Giustetto et al., 2016, 2017). The systematic presence of white mica has also been ascertained in most greenstone geologic specimens from the secondary deposits of the Beigua massif (feasible supply sources for the southeastern Piedmont sites; Giustetto et al., 2018). Also, such a mineral has hardly been reported in samples from primary and/or secondary deposits in the Monviso massif and Po valley (Váczy 
et al., 2019), i.e. the areas that might geographically better suit the reservoir for the supply of raw materials by the local gatherers. Only in the southern Monviso massif (i.e. opposite to Chiomonte) were K-micas (such as phengite and muscovite) seldom observed (D'Amico, 2012). Hence, the absence of white mica(s) might support the idea that the origin of the Chiomonte tools being from Monviso. In this respect, detection of white micas (even by XRPD) might indeed represent a general marker in order to preliminarily infer the provenance of a given implement from a certain supply area, i.e. the Beigua (Voltri) or Monviso massifs, where they are either abundant or rare, respectively. However, such an opinion is not shared by others, according to whom this issue (especially when muscovite is concerned) should not be considered discriminant (Pétrequin et al., 2012a). Similarly, chlorite is frequently observed in geological samples and artefacts of Beigua origin (Giustetto et al., 2017, 2018) but rare in the Chiomonte tools (Tables 2 and 3). Even then, detection of chlorite as a marker for an origin from Monviso is debated (Pétrequin et al., 2012a). The mineralogy of CMIX/81 (axe heel) is intriguing: in addition to tiny omphacitic exsolutions (reminiscent of those described by Schertl et al., 2012) and paragonite, discrete amounts of albite also appear. Its marked alteration and low density $\left(3.18 \mathrm{~g} \mathrm{~cm}^{-3}\right)$ is consistent with those of a "retromorphosed jadeitite" (D'Amico, 2012), an issue typical of geological samples from the southern Monviso or the central Voltri massifs. Similar features also occur in 67 138/4148 (Fig. 2a (iii), Table S1), which is not analysed in depth as it is one of the few complete artefacts.

Another marker might be represented by the pseudomorphs of (white mica and epidote) after lawsonite, systematically observed in greenstone tools from the lower Piedmont and Lombardy sites (e.g. Castello di Annone, Brignano Frascata and Rivanazzano: D'Amico and Starnini, 2012a; Giustetto et al., 2016, 2017), as well as in geologic samples from the areas of presumed supply (Giustetto et al., 2018), but apparently lacking in the Chiomonte artefacts. Presence of these pseudomorphs in greenstone rocks from the Monviso massif is disputed: according to some authors, they should be typical of this area (especially in omphacitites and eclogites; Pétrequin et al., 2012a), whereas others do not report them either in Monviso or in secondary deposits in the Po valley (Váczi et al., 2019). Moreover, the presence of rutile and apatite in the Chiomonte greenstone tools (Table 3) is open to interpretation: the former, considered a marker of Monviso provenance (D'Amico, 2012), is also observed in most Brignano Frascata tools of presumed Voltri (Beigua) origin (Giustetto et al., 2017). The latter, believed to be symptomatic of a Beigua source (Pétrequin et al., 2012a), was also detected in greenstone pebbles from alluvial sediments of the Po valley (Váczi et al., 2019). Blue-green pyroxene crystals, similar to those observed in Chiomonte, have also been reported in the Castello di Annone tools (Giustetto et al., 2016). This may suggest either a common source for the raw materials or that trade relationships occurred between these sites, which is consistent with their coeval dating (from the middle Neolithic onwards). However, similar pleochroic crystals also appear in the tools of other sites located to the east (Giustetto et al., 2017). Moreover, the bluish hue of the Castello di Annone pyroxenes is justified by relatively high $\mathrm{Ti}$ contents $\left(\mathrm{TiO}_{2}\right.$ up to $\left.5 \mathrm{wt} \%\right)$, whereas lower ones $\left(\mathrm{TiO}_{2}<1 \mathrm{wt} \%\right)$ appear in the Chiomonte artefacts.

Garnets with an atoll-like habit similar to the eclogite tools from Chiomonte are also described in the Castello di Annone artefacts, further supporting the hypothesis of a common origin or trade and exchanges having occurred. Such a habit is quite common in garnets from Monviso but rarer than in those from Beigua. Moreover, the lack of quartz-albitejadeitites and omphacite schists in the Chiomonte tools, rocks found only in the Voltri massif (D'Amico and Starnini, 2006; D'Amico, 2012; Pétrequin et al., 2012a), corroborates a possible origin from Monviso. The most compelling evidence about the provenance of the Chiomonte artefacts is the total absence of glaucophanite in the many heterogeneous artefacts made of rocks other than greenstones (Fig. 3b). As inferred by A. M. Pétrequin et al. (2012), the lack of this lithotype, which is found only in the Voltri massif (D'Amico, 2012), strongly supports an origin from the Monviso area.

Most mineralogical and petrographic features of the Chiomonte tools therefore indicate the nearby Monviso massif as the feasible area of provenance. However, some closer areas cannot be ruled out a priori, such as the Rocciavré and the lower Susa-Lanzo-Orsiera (SLO) meta-ophiolite units (e.g. Cadoppi et al., 2002), cropping out on the left (northern) side of the middle and lower Susa Valley and in the Orsiera-Rocciavré mountain range, between the Susa and Sangone valleys, within $20 \mathrm{~km}$ from Chiomonte as the crow flies (Fig. 1b). These units were also affected by eclogite facies metamorphism during the alpine orogeny. Primary outcrops of $\mathrm{Na}$ pyroxene rocks are rarely reported there: a decimetre-thick omphacitite layer occurs at Balangero mine, at the contact between the gneisses of the Sesia-Lanzo Zone and the serpentinites of the northern part of the Lanzo ultramafic massif, belonging to the SLO unit (Compagnoni and Sandrone, 1986), and there is no known occurrence of jadeitite. Nonetheless, scarce and small jade boulders have been reported from the alluvial and glacial deposits of the Susa Valley and of the Rivoli-Avigliana end moraine system at the outlet of the same valley (Piolti, 1898-1899, 19011902; Franchi, 1903; A. M. Pétrequin et al., 2012; P. Pétrequin et al., 2012a).

A peculiarity of Chiomonte is the retrieval of ornamental and recreational objects, hardly found in other sites, made of chloritite (pendants; Fig. 2a, v and $\mathrm{x}$ ) and serpentinite (taws; Fig. 2a, ix), i.e. "softer" lithotypes that are easier to model. A careful selection of raw materials might thus have been undertaken by the Chiomonte artisans, depending on their purposes: probably, sensu stricto greenstones were intended for instruments for cutting because of their particular toughness (still, the abundance of serpentinite in these tools suggests 
that this interpretation should be taken cautiously). Finally, the 5747 axe head fragment shows a peculiar mineralogical composition with abundant garnet, predominating over plagioclase, chlorite, and amphibole, and little omphacite. Such a composition may be ascribed to an "omphacite-garnetite" (see Table 2), a peculiar lithology actually considered by Giustetto and Compagnoni (2014) in their petrographic classification of HP metaophiolites but never found before in a greenstone archaeological implement (Giustetto et al., 2018).

\subsection{Archaeological issues and archaeometric implications}

The Piedmont region represents an important area for analysing the trade and exchange circuits of greenstone artefacts that spread over Europe during the Neolithic, bordered to the west and south by the Monviso and Voltri massifs, respectively (the two main sources of supply in the Western Alps; Pétrequin et al., 2005a, 2006; Lunardi, 2008a; Pétrequin and Pétrequin, 2012; A. M. Pétrequin et al., 2012; P. Pétrequin et al., 2012a, b; Forno et al., 2015). The relatively small set of polished tools from Chiomonte is considered to have utilitarian purposes in a sort of "habitat" environment (Pétrequin and Pétrequin, 2017). A peculiarity is represented by the absence of disc rings, retrieved instead elsewhere (e.g. Brignano Frascata, Villaromagnano, Momperone; Giustetto et al., 2017), coupled with the recovery of playing objects (taws) made of serpentinite, seemingly exclusive of this settlement. Unfortunately, little can be inferred about their provenance, due to the ubiquitous distribution of this rock in the Western Alps (D'Amico et al., 2004; D'Amico and Starnini, 2006). Recently, the most attention has been devoted to the bigger (15-36 cm long), ultra-polished jade axes, used for trade and ceremonial purposes in the Western Europe and Northern Europe (France, Germany, Benelux and Great Britain; Pétrequin et al., 2005a, b; 2017a; Zamagni, 1996; Lunardi, 2008b, Lunardi and Starnini, 2010/2011). Another important factor is the examination of the roughouts, essential in those sites where a consistent record exists (Mancusi, 2016), which may retain clues about the nature and shape of the raw materials, providing information about their origin (whether detached by thermal shocks from primary outcrops at high altitude or moulded from pebbles and cobbles from secondary alluvial deposits; D' Amico and Starnini, 2012b; Pétrequin et al., 2017b). The morphotypological examination of the roughouts, splinters and broken blades marks Chiomonte as a manufacturing site. The presence of elongated chisels with parallel sides and narrow blades (mostly in eclogite) is symptomatic of an economy aimed at production purposes. On some roughouts, superficial portions (untouched by moulding and shaping) show raw surfaces, reminiscent of the cobbles or pebbles from which they had been obtained. Moreover, greenstone pebbles, raw material destined for further production, were found among the artefacts. Such lines of evidence indicate that most (if not all) of the materials used for these artefacts was collected from secondary deposits. Their small-to-modest size further supports this assumption, backed also by chronological issues, as from the late Neolithic onwards the exploitation at high altitudes of these lithologies apparently started to decline (Mancusi, 2016). The Chiomonte site must be contextualised in the Western Alps setting, where shaping of the roughouts was carried out in areas close to the supply sources (Thirault, 2005), once collected from secondary deposits in the nearby geological units. Reasonably, the period testifying the bigger expansion of the Chiomonte site stands between 4200 and $3500 \mathrm{BCE}$, similar to what was observed in other close-by and long-occupied settlements in France (Savoy, Tarantaise and Maurienne; Padovan, 2017).

\section{Summary and conclusion}

A thorough study was performed on the polished stone industry from the archaeological site of Chiomonte, La Maddalena, dating back to the middle to late Neolithic with both archaeometric and morpho-typological issues. Particular care was devoted to studying the greenstone artefacts, which represent by far the most significant rock types used on the Po Plain in prehistory for the production of tools, distributed even in areas very far from their sources.

A theory has been raised by archaeologists, according to which the exploitation of supply sources (from the Monviso and Voltri massifs) and production of greenstone tools might have induced, from the early Neolithic on, a sort of hierarchical organisation. First-order sites (e.g. Alba; VenturinoGambari and Zamagni, 1996; D'Amico and Ghedini, 1996) were meant to be important centres of supply (from both primary and secondary sources) and distribution, with an intense and refined production that exceeded local needs. At second-order sites (e.g. Brignano Frascata, Giustetto et al., 2017), all the production steps (splintering, shaping and bush hammering) were carried out, but the supplies were limited by their own needs and stocked up from local secondary deposits, as shown by the moderate dimensions of the tools and roughouts derived from pebbles (the surfaces of which are somewhat preserved; Mancusi, 2016). The abundance of roughouts and broken tools indicates that Chiomonte was a second-order manufacturing site, although it is hard to assess whether such an activity was confined to the local needs or involved in the trade, circulation and diffusion on a wider scale.

Most mineralogical and petrographic markers of the Chiomonte tools suggest that the raw materials might originate from the Monviso massif - though other local areas cannot be ruled out. The presence of many roughouts with unmanufactured, raw surfaces and even pebbles, suggests that these rocks might have been picked up from secondary sources, represented by the glacial and alluvial deposits of the adjoining valleys. 
Data availability. Data can be obtained on request by contacting Roberto Giustetto (roberto.giustetto@unito.it).

Supplement. The supplement related to this article is available online at: https://doi.org/10.5194/ejm-32-147-2020-supplement.

Author contributions. RG and RC performed the mineralogical and petrographic analyses. SP took care of all morpho-typological descriptions. LB provided an accurate characterisation of the inspected geological contexts. RG also assembled the manuscript, with contributions from all co-authors.

Competing interests. The authors declare that they have no conflict of interest.

Acknowledgements. The authors are grateful to Marica Venturino of the "Soprintendenza Archeologia, Belle Arti e Paesaggio per le province di Alessandria, Asti e Cuneo" and Viviana Mancusi, who significantly contributed in the archaeological description of the studied prehistoric lithic implements.

The reviewers of this paper (anonymous) are thanked for their careful work, which significantly helped in improving the scientific quality of the manuscript.

Review statement. This paper was edited by Elisabetta Rampone.

\section{References}

Andò, M. C.: La pietra levigata neolitica di Gaione (PR), Studio petroarcheometrico dei litotipi. Unpublished Thesis, Università di Bologna, 1996-1997, 1998.

Bendő, Z., Szakmány, G., Kasztovszky, Maróti, B., Szilágyi, S., Szilágyi, V., and Biró, K. T.: Results of non-destructive SEMEDX and PGAA analyses of jade and eclogite polished stone tools in Hungary, Archeometriai Múhely, Archaeometry Workshop XI, 187-205, 2014.

Bendő, Z., Szakmány, G., Kasztovszky, Z., Biró, K. T., Olah, I., Osztás, A., Harsányi, I., and Szilágyi, V.: High pressure metaophiolite polished stone implements found in Hungary, Archaeol. Anthrop. Sci., 11, 1-25, https://doi.org/10.1007/s12520-018-06186, 2019.

Bernabò Brea, M., Battiston, C., Mazzieri, P., and Ottomano, C.: Un gruppo di figurine fittili dal sito di Ponte Ghiara (Parma), Atti del Convegno "La Neolitizzazione tra Oriente e Occidente", vol. 29II, Udine, 271-289, 2000.

Borgogno, M.: Petrografia delle asce neolitiche della Rocca di Cavour (TO) e di analoghi litotipi affioranti nel Massiccio Ofiolitico del Monviso (Alpi Cozie), unpublished Thesis, Università degli Studi di Torino, 178 pp., 2000.

Cadoppi, P., Castelletto, M., Sacchi, R., Baggio, P., Carraro, F., Giraud, V., and Bellardone, G.: Note illustrative della Carta Geologica d'Italia alla scala 1:50.000, Foglio 154 Susa, Regione
Piemonte, Direzione Regionale Servizi Tecnici di Prevenzione, Torino, 123 pp., 2002.

Caron, J. M. and Saliot, P.: Nouveaux gisements de lawsonite and jadéite dans les Alpes franco-italiennes, CR. Acad. Sci., 268, 3153-3156, 1969.

Chiarenza, N. and Giustetto, R.: L'officina litica di Pertus (Paesana, $\mathrm{CN})$ : testimonianze di lavorazione ed analisi mineropetrografiche, Quaderni della Soprintendenza Archeologica del Piemonte, 25, 13-29, 2010.

Chiari, G., Compagnoni, R., Giustetto, R., and Ricq de Bouard, M.: Metodi archeometrici per lo studio dei manufatti in pietra levigata, in: Le vie della pietra verde. L'industria litica levigata nella preistoria dell'Italia settentrionale, edited by: Venturino Gambari, M., Torino, 5-52, 1996.

Compagnoni R.: HP metamorphic belt of the western Alps, Episodes, 26, 200-204, 2003.

Compagnoni, R. and Sandrone, R.: Omphacite/diopside composite metasomatic reaction rims between Sesia gneisses and Lanzo ultramafics at Balangero near Lanzo (western Alps), International IGCP Meeting on "Ophiolites from Serra Nevada and Cost Range complexes", Davis, California (USA), 5-16 June 1986.

Compagnoni, R., Giustetto, R., Ricq-de-Bouard, M., and Venturino Gambari, M.: Studio archeometrico di reperti neolitici e dell'età del rame in pietra verde levigata: discussione sulle tecniche analitiche ed interpretazione dei risultati. Atti della XXXIX Riunione Scientifica dell'Istituto Italiano di Preistoria e Protostoria, Firenze, 25-27 Novembre 2004, 655-682, 2006.

Compagnoni, R., Rolfo, F., Manavella, F., and Salusso, F.: Jadeitite in the Monviso meta-ophiolite, Piemonte Zone, Italian western Alps, Per. Mineral., 76, 79-89, 2007.

Compagnoni, R., Rolfo, F., and Castelli, D.: Jadeitite from the Monviso meta-ophiolite, western Alps: occurrence and genesis from an oceanic plagiogranite, Eur. J. Mineral., 24, 333-343, 2012.

D'Amico, C.: Neolithic "greenstone" axe blades from Northwestern Italy across Europe: a first petrographic comparison, Archaeometry, 47, 235-252, 2005.

D'Amico, C.: Jades and other greenstones from the Western Alps. A petrographic study of the geological sampling Jade, in: Jade, Grandes haches alpines du Néolithique européen, edited by: Pétrequin, P., Cassen, S., Errera, M., Klassen, L., Sheridan, A., Pétrequin, A. M., chap. 7, Presses Universitaires de FrancheComté Ed., Besançon, 420-439, 2012.

D'Amico, C. and De Angelis, M.C.: Neolithic greenstone in Umbria, from the Bellucci Collection. Petrography, provenance, interpretation, Rend. Fis. Acc. Lincei, 20, 61-76, 2009.

D’Amico, C. and Ghedini, M.: La pietra levigata della Collezione Traverso di Alba nel Museo Etnografico "L. Pigorini” di Roma, Atti $10^{\circ}$ Congresso A.N.M.S., Bologna 1994, Museologia Scientifica 13, Supplemento, 292-312, 1996.

D'Amico, C. and Starnini, E.: Eclogites, jades and other HP metaophiolites of the Neolithic polished stone tools from Northern Italy, Kristallinikum, 26, 11-20, 2000.

D'Amico, C. and Starnini, E.: L'atelier di Rivanazzano (PV): un' associazione litologica insolita nel quadro della "pietra verde" levigata in Italia, in: Preistoria dell' Italia settentrionale, Studi in ricordo di Bernardino Bagolini, edited by: Pessina, A. and Visentini, P., Atti del Convegno, Udine, settembre 2005, Udine, Edizioni del Museo Friulano di Storia Naturale, 37-54, 2006. 
D'Amico, C. and Starnini, E.: Circulation et provenance des “ roches vertes " néolithiques d'Italie du Nord, in: Jade, aspects of social inequality in Neolithic Europe, the circulation of large axeheads made from Alpine jades, Book of abstracts, Colloque International, Besançon, 9-12, 24-26 Septembre 2009, 2009.

D'Amico, C. and Starnini, E.: Les "Roches Vertes" Alpines. Productions et circulations Néolithique en Italie Septentrionales, in: Les Hommes Préhistorique et les Alpes. Document du Département de géographie et environnement de l'Université de Genève, edited by: Borrello, M., British Archaeological Reports, International Series 2476, 2013, 125-134, 2011.

D'Amico, C. and Starnini, E.: La production d'outils de pierre en Italie du nord vue depuis l'atelier de Rivanazzano (province de Pavie, Lombardie): matières premières et chaîne opératoire, in: Actes de la Table Ronde de Saint-Germain-en-Laye, edited by: De Labriffe, P. A. and Thirault, É., 16 et 17 Mars 2007, Musée d'Archéologie Nationale, Paris, Société préhistorique française, 2012, 235-243, ISBN 2-913745-47-4, 2012a.

D'Amico, C. and Starnini, E.: Circulation and provenance of the Neolithic "greenstone" in Italy, in: Jade, Grandes haches alpines du Néolithique européen, edited by: Pétrequin, P., Cassen, S., Errera, M., Klassen, L., Sheridan, A., and Pétrequin, A. M., chap. 12, Presses Universitaires de Franche-Comté Ed., Besançon, 728-743, 2012b.

D’Amico, C., Felice, G., and Ghedini, M.: Lithic supplies in the early Neolithic to Sammardenchia (Friuli), Northern Italy, Science and Technology for Cultural Heritage, 1, 159-176, 1992.

D’Amico, C., Campana, R., Felice, G., and Ghedini, M.: Eclogites and jades as prehistoric implements in Europe. A case of petrology applied to Cultural Heritage, Eur. J. Mineral., 7, 2941, 1995.

D’Amico, C., Felice, G., Gasparotto, G., Ghedini, M., Nannetti, M. C., and Trentini, P.: La pietra neolitica di Sammardenchia (Friuli), Catalogo petrografico, Mineralogica et Petrografica Acta, 40, 385-442, 1997.

D’Amico, C., Starnini, E., Gasparotto, G., and Ghedini, M.: Eclogites, jades and other HP-metaophiolites employed for prehistoric polished stone implements in Italy and Europe, Period. Mineral., 73, 17-42, 2004.

D’Amico, C., Nenzioni, G., Fabris, S., Ronchi, S., and Lenzi, F.: Neolithic tools in S. Lazzaro di Savena (Bologna). A petroarchaeometric study, Rendic. Lincei, 24, 23-38, 2013.

Damour, M. A.: Analyse du jade oriental: réunion de cette substance à la tremolite, Ann. Chim. Phys., 317, 469-474, 1846.

Debelmas, J.: Carte géologique de la France à 1/250 000, Feuille 30, Annecy, Editions du BRGM, Orléans, 1980.

Errera, M., Hauzeur, A., Pétrequin, P., and Tsonev, T.: Etude spectroradiométrique d'une lame de hache trouvée dans le district de Chirpan (Bulgarie), in: Interdisciplinary Studies, XIX, Sofia, Archaeological Institute and Museum - Bas, 7-24, 2006.

Errera, M., Pétrequin, P., and Pétrequin, A. M.: Spectroradiométrie, référentiel naturel et étude de la diffusion des haches alpines (Spectroradiometry, raw material reference samples and the diffusion of Alpine axeheads), in: Jade, Grandes haches alpines du Néolithique européen, edited by: Pétrequin, P., Cassen, S., Errera, M., Klassen, L., Sheridan, A., and Pétrequin, A. M., chap. 8, Presses Universitaires de Franche-Comté Ed., Besançon, 440533, 2012.
Forno, M. G., Avondetto, S., Groppo, C. T., and Rolfo, F.: The Quaternary succession of the Bulé and Alpetto valleys (Monviso Massif, Piedmont) as possible supply for prehistoric jade axes raw material, Rend. Fis. Acc. Lincei, 26, 13-20, 2015.

Franchi, S.: Sopra alcuni giacimenti di rocce giadeitiche nelle Alpi Occidentali e nell'Appennino Ligure, Boll. R. Comit. Geol. It., 4, 119-158, 1900.

Franchi, S.: Sul rinvenimento di nuovi giacimenti di roccie giadeitiche nelle Alpi Occidentali e nell'Appennino Ligure, Boll. Soc. Geol. Ital., 22, 130-134, 1903.

Gastaldi, B.: Studi geologici sulle Alpi Occidentali, Mem. Descr. Carta Geol. Italia, 1, 1-36, 1871.

Giustetto, R., Chiari, G., and Compagnoni, R.: An easy noninvasive $\mathrm{X}$-ray diffraction method to determine the composition of Na-pyroxenes from high-density "greenstone" implements, Acta Crystallogr., A64, 161-168, 2008.

Giustetto, R. and Compagnoni, R.: Petrographic classification of unusual high-pressure metamorphic rocks of archaeometric interest, Eur. J. Mineral., 26, 635-642, 2014.

Giustetto, R., Perrone, U., and Compagnoni, R.: Neolithic polished greenstone industry from Castello di Annone (Italy): mineropetrographic study and archaeometric implications, Eur. J. Mineral., 28, 889-905, 2016.

Giustetto, R., Venturino, M., Barale, L., d'Atri, A., and Compagnoni, R.: The Neolithic greenstone industry of Brignano Frascata (Italy): Archaeological and archaeometric study, implications and comparison with coeval sites in the Grue, Ossona and Curone valleys, J. Archaeol. Sci., 14, 662-691, 2017.

Giustetto, R., Barale, L., and Compagnoni, R.: Mineralpetrographic study of greenstone cobbles from Quaternary alluvial deposits and Oligocene conglomerates of the Lemme valley (northwestern Italy): Comparison with analogous Neolithic polished stone implements and archaeometric implications, J. Archaeol. Sci., 19, 312-322, 2018.

Harlow, G. E., Tsujimori, T., and Sorensen, S. S.: Jadeitites and Plate Tectonics, Annu. Rev. Earth Pl. Sc., 43, 105-138, 2014.

Kerckhove, C., Barféty, J. C., Bogdanoff, S., and Lemoine M.: Carte géologique de la France à 1/250 000, Feuille 35, Gap. Editions du BRGM, Orléans, 1980.

Lunardi, A.: La selezione delle materie prime e il loro utilizzo durante l'Olocene, Un'applicazione ai siti neolitici di Quinzano e Rivoli nella Valle dell'Adige (Verona), Rivista di Scienze Preistoriche, LVIII, 59-74, 2008a.

Lunardi, A.: Experimental testing with polished greenstone axes and adzes: technology and use, in: Prehistoric Technology 40 years later: functional studies and the Russian legacy, edited by: Longo, L., and Skatun, N., Proceedings of the International Congress, Verona (Italy), 20-23 April 2005, Oxford (BAR. International series, 1783), 369-373, 2008b.

Lunardi, A. and Starnini, E.: Tipologia, uso e materie prime delle industrie in pietra non scheggiata della cultura dei VBQ: materiali dal Veneto e dalla Liguria a confronto, in: Atti della Società per la Preistoria e la Protostoria della Regione Friuli-Venezia-Giulia, XVIII, 53-86, 2010/2011.

Mancusi, V. G.: Produzione, funzione e circolazione degli abbozzi di asce in pietra verde nel territorio piemontese durante il Neolitico, Quaderni della Soprintendenza Archeologica del Piemonte, 31, 13-34, 2016. 
Mancusi, V. G.: De l'Italie du Sud à Malta, in: Jade, Objetssignes et interprétations sociales des jades alpins dans l'Europe néolithique, edited by: Pétrequin, P., Gauthier, E., and Pétrequin, A. M., Tome 3, chap. 16, Presses Universitaires de FrancheComté Ed., Besançon, 395-418, 2017.

Mannoni, T. and Starnini, E.: Il contributo delle analisi petrografiche nello studio dell'officina litica di Rivanazzano (PV), in: Le scienze della terra e l'archeometria, edited by: D'Amico, C. and Campana, R., Università di Bologna, 21, 1994.

McClure, S.: Jadeite/omphacite nomenclature question, GIA News from Research, 10 April 2012, available at: https://www.gia.edu/ ongoing-research/the-jadeite-omphacite-nomenclature-question (last access: 27 January 2020), 2012.

Morimoto, N., Fabries, J., Ferguson, A. K., Ginzburg, I. V., Ross, M., Seifert, S. A., Zussman, J., Aoki, K., and Gottardi, G.: Nomenclature of pyroxenes, Am. Mineral., 73, 1123-1133, 1988.

Ou Yang, M. C. M.: The development of Fei Cui's study in China, Proceedings of the First International Gem and Jewelry Conference, Gemological Institute of Thailand, Bangkok, p. 44, 6-9 December 2006.

Ou Yang, M. C. M., Yen, H. K., Ng, M. F. Y., and Chan, S. Y.: Nomenclature and classification of Fei Cui (pyroxene jade), Proceedings of International Symposium on Jade, Peking University, Beijing, 23-34, 1-2 September 2011.

Padovan, S.: Il sito di Chiomonte La Maddalena nel quadro del Neolitico recente-finale dell' arco alpino occidentale. Aspetti cronologici e culturali, in: Pionieri delle Alpi, Il pieno Neolitico tra le Alpi Occidentali, edited by: Gambari, F. M., Ferrero, M., and Padovan, S., Atti del Congresso, Chiomonte, Palazzo Levis, 16/17 Novembre 2007, Tipo Stampa Srl, Moncalieri (TO), 4956, 2017.

Pedrotti, A.: La pietra levigata nei corredi delle sepolture neolitiche dell'Italia Settentrionale, in: Le vie della pietra verde. L'industria litica levigata nella preistoria dell'Italia settentrionale, edited by: Venturino Gambari, M., Torino, 150-164, 1996.

Pétrequin, A. M., Pétrequin, P., Errera, M., and Prodéo, F.: Prospections alpines et sources de matières premières, Historique et résultats, in: Jade, Grandes haches alpines du Néolithique européen, edited by: Pétrequin, P., Cassen, S., Errera, M., Klassen, L., Sheridan, A., and Pétrequin, A. M., chap. 2, Presses Universitaires de Franche-Comté Ed., Besançon, 46-183, 2012.

Pétrequin, P. and Errera, M.: Spectroradiométrie, approches macroscopiques et origine des jades alpins: Viso ou Beigua, in: Jade, Objets-signes et interprétations sociales des jades alpins dans l'Europe néolithique, edited by: Pétrequin, P., Gauthier, E., and Pétrequin, A. M., Tome 3, chap. 4, Presses Universitaires de Franche-Comté Ed., Besançon, 75-86, 2017.

Pétrequin, P. and Pétrequin, A. M.: Chronologie et organization de la production dans le massif du Mont Viso, in: Jade, Grandes haches alpines du Néolithique européen, edited by: Pétrequin, P., Cassen, S., Errera, M., Klassen, L., Sheridan, A., and Pétrequin, A. M., chap. 4, Presses Universitaires de Franche-Comté Ed., Besançon, 214-257, 2012.

Pétrequin, P. and Pétrequin, A. M.: À l'origine des routes du jade alpin: specialisation régionale et premiers transferts, in: Jade, Objets-signes et interprétations sociales des jades alpins dans l'Europe néolithique, edited by: Pétrequin, P., Gauthier, E., and
Pétrequin, A. M., Tome 3, chap. 14, Presses Universitaires de Franche-Comté Ed., Besançon, 323-361, 2017.

Pétrequin, P., Errera, M., Cassen, S., and Croutsch, C.: Les Matières Premières Lithiques en Préhistoire, Aurillac: Table Ronde Internationale, 253-275, 2002.

Pétrequin, P., Pétrequin, A. M., Errera, M., Cassen, S., Croutsch, C., Klassen, L., Rossy, M., Garibaldi, P., Isetti, E., Rossi, G., and Delcaro, D.: Beigua, Monviso e Valais. All'origine delle grandi asce levigate di origine alpina in Europa occidentale durante il V millennio, Rivista di Scienze Preistoriche, 55, 265-322, 2005a.

Pétrequin, P., Errera, M., Cassen, S., Billand, G., Colas, C., Maréchal, D., Prodéo, F., and Vangele, F.: Des Alpes italiennes à l'Atlantique: les quatre grandes haches polies de Vendeuil et Maizy (Aisne), Brenouille (Oise), Hommage à Claudine Pommepuy, Revue archéologique de Picardie, 22, 75-104, 2005b.

Pétrequin, P., Errera, M., Pétrequin, A. M., and Allard, P.: The Neolithic quarries of Mont Viso, Piedmont, Italy: initial radiocarbon dates, Eur. J. Archaeol., 9, 7-30, 2006.

Pétrequin, P., Sheridan, A., Cassen, S., Errera, M., Gauthier, E., Klassen, L., Le Maux, N., and Pailler, Y.: Neolithic Alpine axeheads, from the Continent to Great Britain, the Isle of Man and Ireland, in: Between foraging and farming, APL, 40, 262-279, 2008.

Pétrequin, P., Errera, M., Cassen, S., Gauthier, E., Hovorka, D., Klasen, L., and Sheridan, A.: From Mont Viso to Slovakia: the two axeheads of Alpine jade from Golianovo, Acta Archaeologica Academiae Scientiarum Hungaricae, 62, 243-268, 2011.

Pétrequin, P., Errera, M., and Rossy, M.: Viso ou Beigua: approche pétrographique du référentiel des "jades alpins", in: Jade, Grandes haches alpines du Néolithique européen, edited by: Pétrequin, P., Cassen, S., Errera, M., Klassen, L., Sheridan, A., and Pétrequin, A. M., chap. 6, Presses Universitaires de FrancheComté Ed., Besançon, 292-419, 2012a.

Pétrequin, P., Cassen, S., Klassen, L., and Valcarce, R. F.: La circulation des haches carnacéennes en Europe occidentale, in: Jade, Grandes haches alpines du Néolithique européen, edited by: Pétrequin, P., Cassen, S., Errera, M., Klassen, L., Sheridan, A., and Pétrequin, A. M., chap. 18, Presses Universitaires de Franche-Comté Ed., Besançon, 1015-1045, 2012 b.

Pétrequin, P., Cinquetti, M., and Buthod-Ruffier, D.: Le choix des jades alpins, in: Jade, Objets-signes et interprétations sociales des jades alpins dans l'Europe néolitique, edited by: Pétrequin, P., Gauthier, E., and Pétrequin, A. M., Tome 3, chap. 2, Presses Universitaires de Franche-Comté Ed., Besançon, 47-67, 2017a.

Pétrequin, P., Pétrequin, A. M., Gauthier, E., and Sheridan, A.: Mécanismes sociaux: les interpretations idéelles des jades alpins, in: Jade, Objets-signes et interpretations sociales des jades alpins dans l'Europe néolitique, edited by: Pétrequin, P., Gauthier, E., and Pétrequin, A. M., Tome 3, chap. 21, Presses Universitaires de Franche-Comté Ed., Besançon, 521-599, 2017 b.

Piana, F., Fioraso, G., Irace, A., Mosca, P., d'Atri, A., Barale, L., Falletti, P., Monegato, G., Morelli, M., Tallone, S., and Vigna, G. B.: Geology of Piemonte region (NW Italy, Alps-Apennines interference zone), J. Maps, 13, 395-405, 2017.

Piolti, G.: Sulla presenza della jadeite nella valle di Susa, Atti Reale Academia delle Scienze di Torino, XXXIV, 600-608, 18981899. 
Piolti, G.: I manufatti litici del "Riparo sotto roccia" di Vayes (Val di Susa), Osservazioni petrograche, Atti Reale Academia delle Scienze di Torino, XXXVII, 476-491, 1901-1902.

Přichystal, A. and Trnka, G.: Raw materials of polished artifacts from two Lengyel sites in Lower Austria, Slovak Geological Magazine, 7, 337-339, 2001.

Ricq-de-Bouard, M.: Trade in Neolithic jadeite axes from the Alps: new data, in: Trade and Exchange in Prehistoric Europe, edited by: Scarre, C. and Healy, F., Oxford Monographs, 33, 61-67, 1993.

Schertl, H. P., Maresch, W. V., Stanek, K. P., Hertwig, A., Krebs, M., Baese, R., and Sergeev, S. S.: New occurrences of jadeitite, jadeite quartzite and jadeite-lawsonite quartzite in the Dominican Republic, Hispaniola: petrological and geochronological overview, Eur. J. Mineral., 24, 199-216, 2012.

Spišiak, J. and Hovorka, D.: Jadeite and Eclogite: peculiar raw materials of Neolithic/Aeneolithic stone implements in Slovakia and their possible sources, Geoarcheology, 20, 229-242, 2005.

Thirault, E.: The politics of supply: the Neolithic axe industry in Alpine Europe, Antiquity, 79, 34-50, 2005.
Tsonchev, D.: New found antiquities in the Plovdiv region, Proceedings of the Archaeological Institute, 15, 209 pp., 1946.

Váczi, B., Szakmány, G., Starnini, E., Kasztovszky, Z., Bendő, Z., Nebiacolombo, F., Giustetto, R., and Compagnoni, R.: Characterization of HP meta-ophiolite blocks and cobbles from Northern Italy primary outcrops and secondary deposits, as possible raw material sources for the production of "greenstone" prehistoric tools: petrographic investigation and archaeological assessment, Eur. J. Mineral., 31, 905-917, 2019.

Venturino Gambari, M. and Zamagni, B.: Castello di Annone, in: Le vie della pietra verde. L'industria litica levigata nella preistoria dell'Italia settentrionale, Omega Ed., Torino, 98-105, 1996.

Zamagni, B.: L'ascia come simbolo. Prestigio, distinzione sociale, accumulo di ricchezza, in: Le vie della pietra verde, L'industria litica levigata nella preistoria dell'Italia settentrionale, edited by: Venturino Gambari, M., Omega Ed., Torino, 144-145, 1996. 